\title{
The effects of livestock grazing and climate variation on vegetation and grasshopper communities in the northern Chihuahuan Desert
}

\author{
DAVID C. LIGHTFOOT'
}

1 Museum of Southwestern Biology, Biology Department, University of New Mexico, Albuquerque, NM, USA, 87131.

Corresponding author: David C. Lightfoot (dlightfo@unm.edu)

Academic editor: Tim Gardiner | Received 1 August 2017 | Accepted 9 November 2017 | Published 12 June 2018

http://zoobank.org/C95315B9-EF67-4505-AD53-76A849F6E645

Citation: Lightfoot DC (2018) The effects of livestock grazing and climate variation on vegetation and grasshopper communities in the northern Chihuahuan Desert. Journal of Orthoptera Research 27(1): 35-51. https://doi.org/10.3897/jor.27.19945

\begin{abstract}
Grasshoppers are important herbivores of North American semi-arid grasslands and shrublands, and vegetation and climate are key factors controlling their species compositions and population dynamics. Domestic livestock grazing is a historic and a current landscape-scale ecological perturbation that has caused reductions of perennial grasses and increases in woody shrubs and weedy annual herbs in desert grassland communities. Climate variation also affects vegetation and grasshopper production, and the combined effects of livestock grazing and climate variation on vegetation and grasshoppers have not been adequately studied in the American Southwest. I measured vegetation and grasshoppers for five years at a series of five semi-arid sites in the northern Chihuahuan Desert to evaluate the interactive effects of short-term livestock grazing and climate variation on plant and grasshopper community structure and species abundances. The study sites ranged from shrub dominated to grass dominated landscapes, with livestock fence lines separating land that was grazed at $30 \%$ annual forage utilization, and lands on the other sides of the fences excluded from grazing for at least 20 years. I assigned grasshopper species to life-form guilds based on their ecomorphologies and their microhabitat substrate uses that I observed. A wet spring/dry summer El Niño event occurred at the beginning of the study, and a dry spring/wet summer La Niña event occurred at the end of the study. Livestock grazing changed plant and grasshopper species compositions and abundances significantly during those wet years, further favoring annual forbs, annual grasses and non-graminicole grasshoppers on grazed lands during wet years, while favoring perennial grasses and graminicoles on non-grazed lands also during wet years. The biotic communities at all sites probably supported more perennial grasses and more graminicoles prior to European settlement and livestock grazing that began over a century before this study.
\end{abstract}

\section{Key words}

Acrididae, desertification, ecological disturbance, guilds, life-forms

\section{Introduction}

Grasshoppers are important primary consumers in semi-arid regions throughout the world (Uvarov 1977), and grasshopper species compositions are determined largely by geographic proximity to evolutionary source regions (Key 1959, Otte 1976) and by species adaptations to local soils and vegetation composition and structure (e.g. Anderson 1964, Mulkern 1967, 1982, Otte and Joern 1977, Joern 1979, 1982, Kang et al. 1989, Fielding and Brusven 1995a, Torrusio et al. 2002, Cigliano et al. 2010, Savitsky 2010). Population densities of many grasshopper species fluctuate widely over time, apparently largely due to bottom-up changes in food plant availability and quality, caused not only by variation in precipitation, but also by physiological responses to variation in temperature and moisture conditions (Rodell 1977, Capinera 1987, Fielding and Brusven 1990, Joern and Gaines 1990, Belovsky and Joern 1995). Density-dependent effects of other grasshoppers, predators, parasitoids, and disease also interact to affect grasshopper populations (Dempster 1963, Street and McGuire 1990). How grasshopper communities and populations respond to environmental disturbance such as domestic livestock grazing and climate change depends to what extent soil, vegetation and weather conditions change in magnitude, space and time, and to what extent different grasshopper species with variable environmental tolerances are affected by the changes. Some species are likely to respond in certain ways, while other species may show different responses (Fielding and Brusven 1996).

Convergence or divergence in grasshopper species ecologies and specializations are likely driven by the evolution of ecological traits (e.g. Van der Plas et al. 2012). Grasshoppers that occur in particular types of habitats and feed on particular types of plants have morphological, physiological and behavioral adaptations, or ecological traits that maximize evolutionary fitness for those species in their particular environments. Grasshopper species that share similar ecological traits for morphology, diet and behavior are ecological guilds; groups of species that exploit the same class of environmental resources in a similar way (Root 1967, Diamond 1975). How one choses to describe grasshopper community structure, including guilds, depends upon the purpose for such description (Lockwood 2011), and the guild concept is useful for understanding higher level ecological structure that may show patterns beyond taxonomically constrained species, tribes, subfamily and family ranks. The grasshopper community guild concept has been used to describe grasshopper community structure for specific assemblages and locations in North America (e.g. Joern and 
Lawlor 1981), China (Hong-Shi 1991, Sun et al. 2013) and Africa (Prendini et al. 1996). Those studies assigned grasshopper species from local assemblages to guilds based on microhabitat and food resource use, which provided good descriptions of the ecological structures of those grasshopper communities.

Uvarov (1977) described grasshopper life-forms that occur globally, and that correspond to ecological/morphological traits of grasshoppers that live in particular types of microhabitats, such as open bare soil, grass, forbs and shrubs and trees. I previously applied Uvarov's life-form concept to describe grasshopper guild structure in North American desert grasshopper communities in the cool-temperate Great Basin Desert and in the warm subtropical Chihuahuan Desert, based on substrate use by individual grasshoppers (Lightfoot 1985). I found that life-forms reflected the ecological traits of grasshopper species: 1) terricoles live on bare soil or rock surfaces and feed on grasses and forbs, 2) herbicoles live and feed on forbs, 3) graminicoles live on and feed on grasses, and 4) arbusticoles live on and feed on woody shrubs (a subset of arboricoles). The life-form guild structure was similar in both deserts, while the species were not. Grasshopper species within life-form guilds should exhibit similar responses to changes in vegetation resources, relative to other responses of species in other guilds. Grasshopper life-form guilds have also proved useful for documenting the effects of burrowing rodents (Cynomys spp.) and livestock grazing on plant and grasshopper communities in the northern Chihuahuan Desert (Davidson and Lightfoot 2008, Davidson et al. 2010). Just as grasshopper species with different ecologies can serve as species indicators of environmental change in local geographic regions (Bazelet and Samways 2011), grasshopper life-form guilds transcend regional taxonomic constraints of species (Uvarov 1977), and have the potential to serve globally as grasshopper life-form guild indicators to environmental change.

Desertification is the anthropogenic environmental degradation of semi-arid grasslands from long-term excessive and unsustainable domestic livestock grazing, that has occurred extensively throughout the semi-arid regions of the world, including the semiarid regions of North America (Nelson 1988). The most intense desertification in North America has taken place in the northern Chihuhuan Desert (Dregne 1986), largely the result of excessive domestic livestock grazing and droughts (York and Dick-Peddie 1969, Dick-Peddie 1993). Unlike more mesic grassland and savanna environments where vegetation and animals are adapted to grazing, domestic livestock are a substantial and unnatural perturbation to semi-arid desert grassland biotic communities that did not evolve with large ungulate grazers (Pieper 1994, Young 1994). Desertification in the Chihuahuan Desert has resulted in a dramatic reduction in the abundance of perennial grasses, and an increase in woody shrubs (Buffington and Herbel 1965, Archer 1994, Pieper 1994). Attempts to better understand and manage natural resources of desertified landscapes are evolving toward better applications of science and ecology to address the problem (Peters et al. 2015). Vegetation changes on North American rangelands associated with domestic livestock grazing and desertification continue to have disruptive impacts on the species composition, diversity, and stability of rangeland grasshopper assemblages and populations (Fleischner 1994, Laycock 1994, Jones 2006). Understanding both the short-term and long-term ecological implications of livestock impacts to grasshoppers (e.g. Fielding and Brusven 1996) will contribute to more sustainable natural resource management.

Livestock grazing typically causes changes to herbaceous vegetation composition and structure that in turn cause shifts in grasshopper species compositions and population densities in savanna, shrub-steppe and desert grassland environments (e.g. Capinera and Sechrist 1982, Jepsen-Innes and Bock 1989, Quinn and Walgenbach 1990, Fielding and Brusven 1993, 1995b, 1996, Prendini et al. 1996, Gebeyehu and Samways 2003, Debano 2006, Kang and Chen 2008, Branson and Sword 2010). Results of studies vary, especially between grasslands/savanna and desert grasslands, but grasshoppers that prefer more open microhabitats with sparser and lower stature vegetation tend to respond more favorably to livestock grazing than those that prefer taller and denser herbaceous vegetation (e.g. Prendini et al. 1996). Livestock grazing also can reduce grasshopper diversity, and favor fewer ecological generalist grasshopper species (e.g. Fielding and Brusven 1993) that can shift the temporal stabilities of such communities, making them more sensitive to changes in climate.

Fielding and Brusven (1996) provided a literature review of livestock grazing effects on semi-arid region grasshoppers of North America. They concluded that there is no one answer to the question of how livestock grazing effects grasshoppers; each situation is different, and each depends upon current and historic grazing regimes, local environments, grasshopper species ecologies, and ecological, temporal, spatial and functional characteristics of the system studied. Of particular importance is the differentiation of short-term (< 10 years) vs. long-term (decades to centuries) effects of grazing on soils, vegetation and grasshoppers. Long-term grazing can permanently change soils, vegetation and grasshoppers, while the impacts of short-term grazing may revert back to original conditions within a few years if grazing ceases (Fielding and Brusven 1996).

Variation in weather or long-term climate is known to be a key factor affecting grasshopper populations (Edwards 1960, Gage and Mukerji 1977, Begon 1983, Capinera and Horton 1989, Fielding and Brusven 1990, Jonas and Joern 2007, Nufio et al. 2010). Therefore, anthropogenic global climate change likely is and will have a significant influence on grasshopper communities, just as it is predicted to have on all biota globally (Parmesan 2006, Rosenzweig et al. 2008). Climate change will not only directly affect grasshopper physiological responses and phenologies (Nufio et al. 2010), but also will interact with other anthropogenic disturbances such as livestock grazing to cumulatively affect grasshoppers (Fielding and Brusven 1995b, 1996, Jonas and Joern 2007, Branson and Sword 2010). As global warming continues to accelerate, the climate of the American Southwest is becoming warmer, drier and the timing and intensity of precipitation more variable (Seager et al. 2008, Gutzler and Robbins 2011, Gutzler 2013), likely intensifying adverse impacts of livestock grazing to vegetation and grasshoppers.

Given that grasshoppers are key primary consumers in semiarid ecosystems across the Southwest, and given that grasshoppers are known to be affected by variation in vegetation caused by livestock grazing and variation in climate, what effects do domestic livestock and climate have on vegetation and grasshoppers in the Southwest? I conducted this research project to address the following questions: 1) Does short-term livestock grazing alter the species compositions, plant life-form (i.e. grass, forb, shrub, tree) and grasshopper life-form guild structures, and abundances of rangeland plants and grasshoppers? 2) Does annual and seasonal variation in precipitation interact with livestock grazing to affect plant and grasshopper species assemblages and grasshopper guild structure? 3) Which grasshopper species and guilds are most sensitive to the impacts of short-term livestock grazing and climate variation?

This research was conducted as part of the U.S. Department of Interior (USDI), Bureau of Land Management (BLM), Global 
Change Research Projects program, 1991-1996, which was intended to support long-term research on the ecological impacts of global climate change to natural resources. However, in 1996, the program was terminated due to politically motivated USDI administrative research program changes. This article presents the findings of the five-year vegetation and grasshopper grazing response research that was conducted from 1992-1996 as part of the Chihuahuan Desert Subproject. This research was intended to be a long-term (decades) study to document biotic community responses to climate change, but the entire Global Change Research Program was terminated, so the long-term goals were not accomplished.

\section{Methods}

Study sites and sampling design.-Study sites for this research were subjectively located where BLM lands within the Chihuahuan Desert in southern New Mexico were adjacent to lands under other ownership and/or management that excluded livestock grazing, and shared a common boundary with a standard 5 strand barbedwire livestock fence. Livestock grazing was present on the BLM side of the fence, but not on the other side. From those potential locations, site selection then depended upon obtaining permission from the other landowner/agency to conduct the study, and then depended upon finding a $1 \mathrm{~km}$ long section of the boundary fence that had relatively homogeneous topography, soils, and vegetation, so that the presence of livestock grazing on the BLM side of the fence, but not on the other side, was the only primary factor that differed along the potential fence line. The grazed side of each fence line was BLM public land that was currently grazed by domestic cattle, and had been historically grazed for at least 20 years. The non-grazed side of the fences had been excluded from cattle for at least 20 years. Grazing intensity at all sites was yearround, approximately 30\% utilization of available plant foliage by domestic livestock, the standard stocking rate for BLM public rangelands in the region. Each site consisted of semi-arid grassland or shrubland that was grazed by domestic cattle, and adjacent non-grazed land on the other side of the barbed-wire livestock fence line. All sites were further chosen to be situated at the same approximate elevation ( 1,500 m above sea level), and all on similar topographic landscapes; lower piedmont slopes with silty to sandy loamy soils. All sites supported Chihuahuan Desert grassland or shrubland vegetation communities. Sites ranged from shrub-dominated to grass-dominated, but all sites had both grass and shrub elements.

The study sites were located in the northern Chihuahuan Desert (Chihuahuan Deserts Level III Ecoregion, Griffith et al. 2006), in south-central New Mexico, USA. The Sevilleta Site was located along the north boundary of the Sevilleta National Wildlife Refuge, Socorro County, and the vegetation was desert grassland dominated by black grama (Bouteloua eriopoda) and blue grama (B. gracilis); the Bosque Site was located along the east boundary fence of Bosque del Apache National Wildlife Refuge, Socorro County, and the vegetation was mixed desert grassland and shrubland dominated by sacaton grasses (Sporobolus spp.) and sand sage (Artemisia filifolia); the Jornada Site was located along the southwest boundary fence of the US Department of Agriculture, Jornada Experimental Range, Doña Ana County, and the vegetation was creosote bush (Larrea tridentata) shrubland; the Phillips Site was located along the east boundary fence of the US Army, White Sands Missile Range at the Phillips Hills, Lincoln County, and the vegetation was creosote bush shrubland; all four sites above were within the
Chihuahuan Basins and Playas Level IV Ecoregion; and the Otero Site was located on the northwestern side of Otero Mesa along the boundary fence of a BLM grazing exclosure, Otero County, and the vegetation was desert grassland dominated by black grama and blue grama, and within the Chihuahuan Desert Grasslands Level IV ecoregion. See Dick-Peddie (1993) for detailed descriptions of the vegetation of those ecoregions in New Mexico. Table 1 provides location information for each site.

Sampling at each site was systematic, not random or subjective. Two $600 \mathrm{~m}$, paired, grazed and non-grazed sampling transects were permanently installed at each of the five study sites. Each of the paired $600 \mathrm{~m}$ measurement transects were located parallel to, and each $20 \mathrm{~m}$ from the fence line between the two, to avoid roads and/or livestock trails along some of the fence lines. Each $600 \mathrm{~m}$ transect was partitioned into thirty, $20 \mathrm{~m}$ segments. All transects and segments were permanently marked and labeled with $0.5 \mathrm{~m}$ steel rods that were hammered into the soil.

Weather.-Weather data were obtained from the nearest long-term U.S. National Weather Service weather station to each of the five study sites. Monthly precipitation amounts and ambient temperatures were summed and averaged respectively over each year of this study. Table 2 presents the name and location of each of the weather stations.

Vegetation. - Vegetation was measured from a $1 \mathrm{~m}^{2}$ quadrat located at the start (north or west end) of each of the thirty, $20 \mathrm{~m}$ segments per transect. The same permanent quadrats were repeatedly sampled over the five-year study period. A $1 \mathrm{~m}^{2}$ vegetation measurement frame made of 0.5 inch PVC pipe with an internal string 10 by 10 grid of 100,1 decimeter $^{2}$ subunits, was used to measure vegeta-

Table 1. Study site information based on center of each site.

\begin{tabular}{|c|c|c|c|}
\hline Study site name & Location & Elevation & Level IV Ecoregion* \\
\hline $\begin{array}{l}\text { Bosque del Apache } \\
\text { National Wildlife Refuge }\end{array}$ & $\mathrm{N} 33^{\circ} 24^{\prime}, \mathrm{W} 106^{\circ} 45^{\prime}$ & $1,520 \mathrm{~m}$ & $\begin{array}{l}\text { Chihuahuan Basins } \\
\text { and Playas 24a }\end{array}$ \\
\hline $\begin{array}{l}\text { Jornada Experimental } \\
\text { Range }\end{array}$ & $\mathrm{N} 32^{\circ} 28^{\prime}, \mathrm{W} 106^{\circ}$ & $1,340 \mathrm{~m}$ & $\begin{array}{l}\text { Chihuahuan Basins } \\
\text { and Playas 24a }\end{array}$ \\
\hline Otero Mesa & $\mathrm{N} 32^{\circ} 29^{\prime}, \mathrm{W} 105^{\circ} 46^{\prime}$ & $1,540 \mathrm{~m}$ & $\begin{array}{l}\text { Chihuahuan Desert } \\
\text { Grasslands 24b }\end{array}$ \\
\hline $\begin{array}{l}\text { Phillips Hills, White } \\
\text { Sands Missile Range }\end{array}$ & $\mathrm{N} 32^{\circ} 27^{\prime}, \mathrm{W} 106^{\circ} 06^{\prime}$ & $1,490 \mathrm{~m}$ & $\begin{array}{l}\text { Chihuahuan Basins } \\
\text { and Playas 24a }\end{array}$ \\
\hline $\begin{array}{l}\text { Sevilleta National } \\
\text { Wildlife Refuge }\end{array}$ & $\mathrm{N} 34^{\circ} 24^{\prime}, \mathrm{W} 106^{\circ} 36^{\prime}$ & $1,610 \mathrm{~m}$ & $\begin{array}{l}\text { Chihuahuan Desert } \\
\text { Grasslands 24b }\end{array}$ \\
\hline
\end{tabular}

${ }^{*}$ Griffith et al. 2006

Table 2. U.S. National Weather Service weather stations that provided weather data for this study. Each of the five study sites was represented by one nearest weather station.

\begin{tabular}{|c|c|c|c|}
\hline Study site name & Weather station name & Location & Elevation \\
\hline $\begin{array}{l}\text { Bosque del Apache } \\
\text { National Wildlife Refuge }\end{array}$ & Bosque del Apache & $\mathrm{N} 33^{\circ} 46^{\prime}, \mathrm{W} 106^{\circ} 54^{\prime}$ & $1,445 \mathrm{~m}$ \\
\hline $\begin{array}{l}\text { Jornada Experimental } \\
\text { Range }\end{array}$ & $\begin{array}{c}\text { Jornada Experimental } \\
\text { Range }\end{array}$ & $\mathrm{N} 32^{\circ} 37^{\prime}, \mathrm{W} 106^{\circ} 44^{\prime}$ & $1,440 \mathrm{~m}$ \\
\hline Otero Mesa & Orogrande & $\mathrm{N} 32^{\circ} 23^{\prime}, \mathrm{W} 106^{\circ} 06^{\prime}$ & $1,270 \mathrm{~m}$ \\
\hline $\begin{array}{l}\text { Phillips Hills, White } \\
\text { Sands Missile Range }\end{array}$ & Carrizozo & $\mathrm{N} 33^{\circ} 39^{\prime}, \mathrm{W} 105^{\circ} 53^{\prime}$ & $1,650 \mathrm{~m}$ \\
\hline $\begin{array}{l}\text { Sevilleta National } \\
\text { Wildlife Refuge }\end{array}$ & Bernardo & $\mathrm{N} 34^{\circ} 25^{\prime}, \mathrm{W} 106^{\circ} 50^{\prime}$ & $1,085 \mathrm{~m}$ \\
\hline
\end{tabular}


tion canopy cover by species. The PVC frame was attached to $1 \mathrm{~m}$ tall legs with height adjustments on each corner to keep it elevated immediately above the plant foliage canopies. The total foliage canopy cover of each plant species, and the maximum foliage height of each plant species per quadrat were recorded. Vegetation was sampled twice each year, at the end of the spring growing season in late May (especially for spring annual C3-photosynthetic pathway plants), and at the end of the summer growing season in late September for most other largely $\mathrm{C} 4$ plants. Vegetation was measured over a period of five years; 1992, 1993, 1994, 1995, and 1996. Plant species classification, common names and Latin names, life-histories and growth-forms follows USDA PLANTS Database (2017).

Grasshoppers._Many different field sampling methods have been utilized to count grasshoppers (Onsager 1977). Most physical sampling methods are biased toward grasshopper species that are either less active than others, or more active than others, depending on the method and the environment. Physical sampling methods also capture and remove grasshoppers from study sites. I chose to use visual transect sampling instead, by slowly walking each of the thirty, $20 \mathrm{~m}$ by $1 \mathrm{~m}$ segments or strips of each transect. All grasshoppers observed in each $20 \mathrm{~m}$ strip transect along each segment were recorded. I walked slowly along each $20 \mathrm{~m}$ strip transect segment, tapping the ground and vegetation with a $1 \mathrm{~m}$ long white $13 \mathrm{~mm}$ diameter PVC pipe to flush all grasshoppers ahead of me as I slowly walked forward. I recorded species, sex, age class, and substrate (physical surface that the individual flushed from) of each grasshopper observed on a voice-activated micro-audio recorder. I had ten years of prior experience visually identifying the regional grasshopper species in the field, and I was the only observer/recorder for this study. Resulting data were the absolute density of each grasshopper species per each $20 \mathrm{~m}$ by 1 $\mathrm{m}$, or $20 \mathrm{~m}^{2}$ transect segment, per sampling period.

The substrate was the physical surface that each grasshopper was first observed on, including soil surfaces, and different species of plants. I watched grasshoppers as they hopped and/or flew ahead of me and did not recount any individuals that I had already counted. Grasshoppers were sampled twice each year during the five-year study period, at the same time that vegetation was measured. Several species of grasshoppers in the region hatch from eggs in the late summer/fall, over-winter as juveniles and become adults in the late spring (e.g. Psoloessa spp., Cibolacris parviceps, Arphia conspersa, Xanthippus spp.). Also, one of the most common grasshoppers in the region, Trimerotropis pallidipennis has two distinct generations each summer in the region of this study, one early and one late (Richman et al. 1993). Most other grasshopper species hatch from eggs in the mid-summer, and become adults in the late summer/fall. Grasshopper sampling was conducted during the late morning to early afternoon hours when grasshoppers tend to be most active. Grasshopper sampling was conducted only when winds were less than 10 miles per hour, the sun was shining, and the soil surface and vegetation were dry. Grasshopper species classification, common names and scientific names follows Cigliano et al. (2017).

I assigned grasshopper species to ecological life-forms following the morphological descriptions of Uvarov (1977). I used multivariate cluster analysis (see McCune and Grace 2002) to evaluate groupings of grasshopper species in this study based on similarities in observed substrate use (see Results) to provide additional ecological information to evaluate grasshopper assemblage guild structure based on resource use (as indicated by substrate use) and morphology (as described by Uvarov 1977).
Data management and analysis. - Vegetation data were entered on field data forms and then transferred to a Microsoft Excel spreadsheet for management and error checking, then converted to a text file for analysis. Grasshopper data were entered from field audio-recordings to an Excel spreadsheet and converted to a text file for analysis. All data were quality checked and verified. The vegetation, grasshopper, and climate data resulting from this study were summarized and analyzed using SAS analytical software (Version 9.4, SAS Institute, Carey, North Carolina, USA). I used hierarchical group-average cluster analysis (SAS; PROC CLUSTER, PROC TREE) utilizing Euclidean distance for similarity measures of species composition or grasshopper substrate use to evaluate entire assemblages of species from different locations, each year and season. Vegetation data were mean canopy covers and heights of each species/quadrat over all 30 quadrats per site, by control and treatment sides of the fence (control vs. grazed; 30 quadrats each). I used paired t-tests (SAS; PROC TTEST) to test for significant differences in vegetation canopy cover and heights between grazed and non-grazed paired fence side locations within sites. I used Chi-square goodness of fit tests (SAS; PROC FREQ) to test for differences in grasshopper counts, summed by species, and categorized by life-forms, from each paired $600 \mathrm{~m}$ transect (non-grazed vs. grazed) at each site and year/season. I used a standard statistical test level of alpha $(p)=0.05$. The relationships between grasshopper life-form counts from individual grasshopper species counts, and available plant life-form and bare soil cover values that were measured from the $1 \mathrm{~m}^{2}$ quadrats, were evaluated with non-parametric Spearman-rank correlation analysis (SAS; PROC CORR).

\section{Results}

Weather.-Annual total precipitation summed over 12 months of each year from 1992-1996 across all five sites, ranged from $10 \mathrm{~cm} /$ year to $40 \mathrm{~cm} /$ year, with an overall decline trend over time, especially in 1995 (Fig. 1). El Niño / Southern Oscillation Events (ENSO) occurred in 1992 and in 1996. A moderate El Niño event occurred in 1991/1992, with above average rainfall during the winter and spring of that period, and weak El Niño events occurred in 1993 and in 1995, followed by a weak La Niña event in 1996, with above average late summer rains (NOAA 2016). The Phillips site had the most precipitation over the 5 year study, except in 1995 , followed by the Otero site (both in the Tularosa Basin, adjacent to the Sacramento Mountains), while the Jornada, Bosque, and Sevilleta sites (all in the Rio Grande valley) tended to be drier over the 5 year study period. Annual average ambient temperatures, averaged over 12 months of each year from 1992-1996 across all 5 sites, ranged from $13.0^{\circ} \mathrm{C}$ to $17.5^{\circ} \mathrm{C}$ across the sites, with an overall increase of one degree centigrade over all 5 sites over the 5 year period, with particularly warm temperatures in 1994 (Fig. 2).

Vegetation.-A listing of all 151 plant species observed, their lifehistories, and life-forms is presented in Suppl. material 2: Table S1. The majority of plant species sampled from all five study sites over the five-year period were herbaceous forbs, followed by grasses, shrubs, and cacti.

Plant species counts or richness ranged from about 15 to 30 species over the study sites and years, with most sites showing declines in 1994 and increases in 1995, and slightly more species were present during late summer/fall sampling than during the early summer/spring (Suppl. material 1: Fig. S1). Some sites like the Bosque and Jornada had slightly greater species richness 


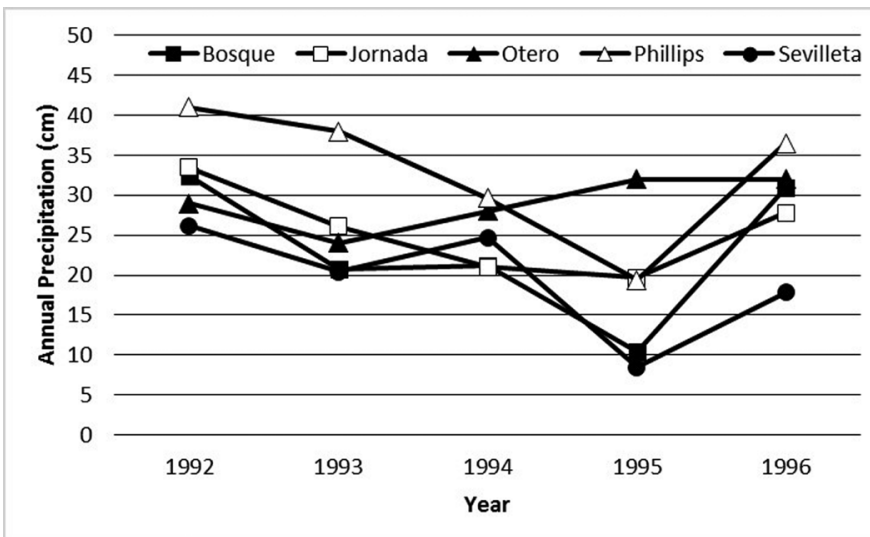

Fig. 1. Total annual precipitation (January-December) at each of the study sites over the five-year study period.

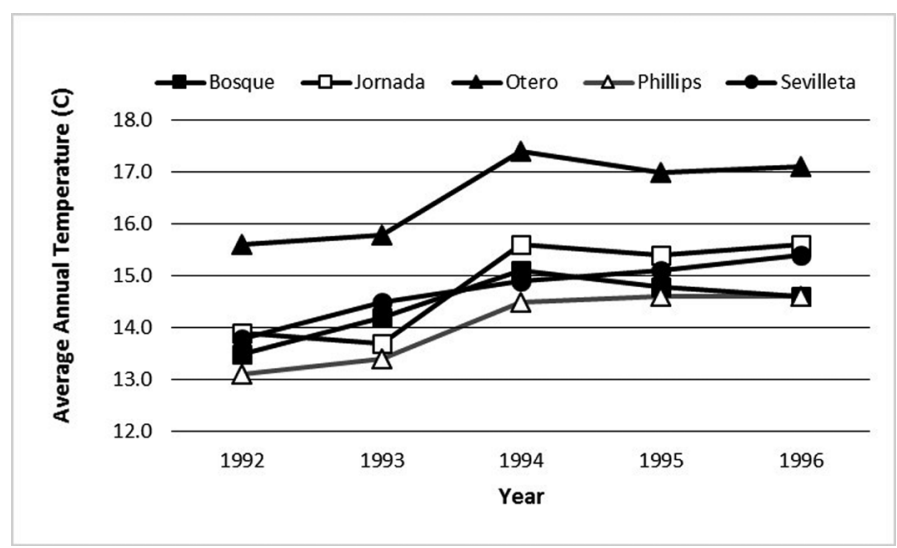

Fig. 2. Annual average (12 months/year) temperatures at each of the study sites over the five-year study period.

on grazed quadrats than on non-grazed quadrats, while the other sites showed greater richness on the non-grazed quadrats.

Cluster analysis of the five study sites and their control vs. grazed sides of the fences, and based on similarities of plant species compositions summed over the five-year period, revealed that each of the sites supported very distinct plant species compositions both in the spring and fall (Fig. 3). The branch or stem lengths of the dendrograms in Fig. 3 demonstrate much more similarity across grazed and non-grazed quadrats within each site, than between sites, and similarities between sites were greater during the spring seasons (Fig. 3A) than in the fall (Fig. 3B) based on cluster branch or stem lengths. Higher level groupings revealed that the Sevilleta, Bosque, and Phillips sites were more similar to each other than the Jornada or Otero sites in the spring, but that the Bosque, Sevilleta and Otero sites were more similar to each other than to the Jornada and Phillips sites in the fall over all five years. The Jornada and Phillips sites were creosote bush dominated shrublands on gravelly alluvial soils, while the Sevilleta, Bosque and Otero sites were black and blue grama grass, and burro (Scleropogon brevifolius) and sacaton grass dominated desert grasslands on finer alluvial and aeolian soils. The Sevilleta site was primarily grassland, the Bosque site also had considerable amounts of sand sage (Artemisia filifolia), and the Otero site had creosote bush but not as dominant as at the Jornada and Phillips sites.

Analysis of the major plant life-forms forbs, grasses, and shrubs, revealed that livestock grazing primarily affected grasses and forbs, but not shrubs (except for broom snakeweed). Across all five sites, forbs and grasses tended to have significantly more cover on the non-grazed sides of the fences than on the grazed sides, especially in association with the 1991/1992 El Niño event, and the $1996 \mathrm{La}$ Niña event (Suppl. material 1: Fig. S2 and Suppl. material 2: Table S2). Spring and summer annual forbs at the Bosque and Otero sites increased significantly on the non-grazed side of the fences in 1995, only spring annual forbs increased in 1995 and on the non-grazed sides of the fences at the Jornada and Sevilleta sites, while annual forbs increased significantly on the grazed side of the fence at the Otero site in 1996 (Suppl. material 1: Fig. S2, Suppl. material 2: Table S2). Grass cover increased significantly in the fall of 1996 on the grazed areas at the Otero and Sevilleta sites, dominated by the annual grass sixweeks threeawn (Aristida adscensionis). Otherwise, grass cover at Otero and Sevilleta sites was dominated by the perennial grama grasses (Bouteloua spp.), and at the Jornada site where perennial bush muhly (Muhlenbergia porteri) was abundant, grass cover was generally significantly greater on the nongrazed areas over the five-year study (Suppl. material 1: Fig. S2). Plant height measurement data also revealed that perennial grasses were not significantly different, or were significantly taller on nongrazed vs. grazed areas at all sites across all years, except for Bosque and Sevilleta sites in 1996, where again, annual sixweeks threeawn created significantly taller grass on the grazed areas (Suppl. material 2: Table S2). Shrub canopy cover and heights tended to vary little over space and time (Suppl. material 1: Fig. S2, Suppl. material 2: Table S2). The only dynamic shrub species was broom snakeweed (Gutierrezia sarothrae) which increased significantly in the spring of 1992 and in the fall of 1996 on grazed areas at the Sevilleta site.

Overall, the canopy cover and abundance of annual forbs and annual grasses varied considerably in response to variation in rainfall over the five sites and five years, especially the late summer of 1996 when annual sixweeks threeawn grass had higher cover and height than perennial grasses at two of the five sites. Perennial grasses tended to be less variable in cover and height over time, but typically with consistently greater cover and height in non-grazed vs. grazed areas over the five years. Forb and grass canopy cover and height either did not significantly differ between grazed and non-grazed areas, or was significantly greater in nongrazed areas than grazed areas. Shrub cover tended to vary little over time, and generally was not significantly different between grazed and non-grazed locations, except for the small, short-lived shrub broom snakeweed that had greater cover in grazed areas following wet periods at the Sevilleta site. The only common exotic weed species, prickly Russian thistle (Salsola tragus), was typically more abundant on grazed than non-grazed lands.

Grasshoppers.-A total of 54 grasshopper species were observed across the sites and years; their names, life-form and life-history status are presented in Table 3. The majority of grasshopper species belonged to the family Acrididae (52), along with two species of Romaleidae. The subfamily Gomphocerinae was represented by 21 species, followed by 16 Oedipodinae, 14 Melanoplinae and one Cyrtacanthacridinae. The majority (45) of grasshopper species were late summer season species, 7 species were spring season, and two species had both spring and fall cohorts (Table 3). Summed numbers of individuals of each grasshopper species across all sites, treatments, years and seasons is presented in Suppl. material 3. Observed substrate use by all grasshopper species over all sites, treatments, years and seasons is presented in Suppl. material 4. Those same substrate use values also provide counts of each grasshopper species summed over the five-year study, and were used 
A

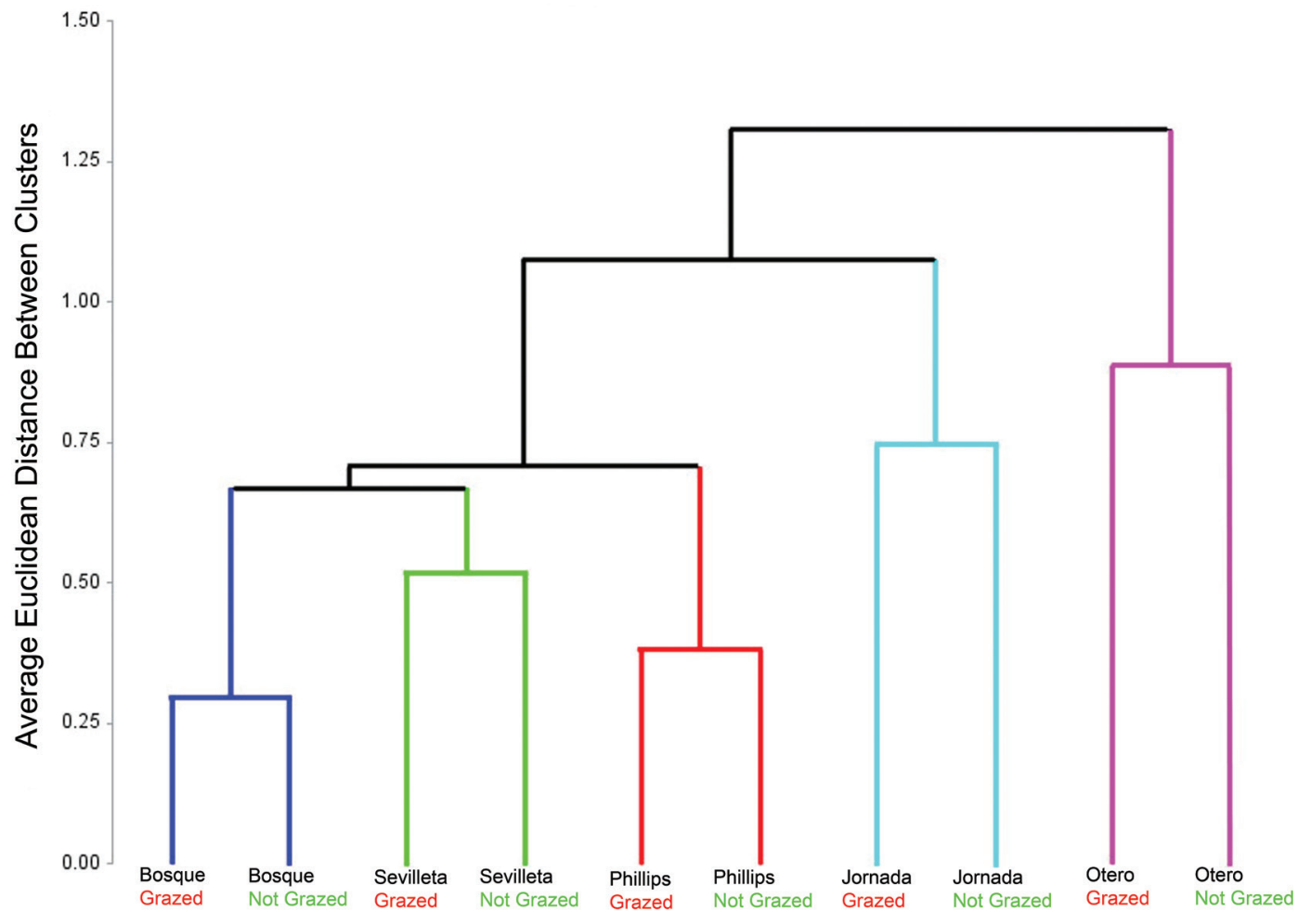

Site and Grazing Treatment

B

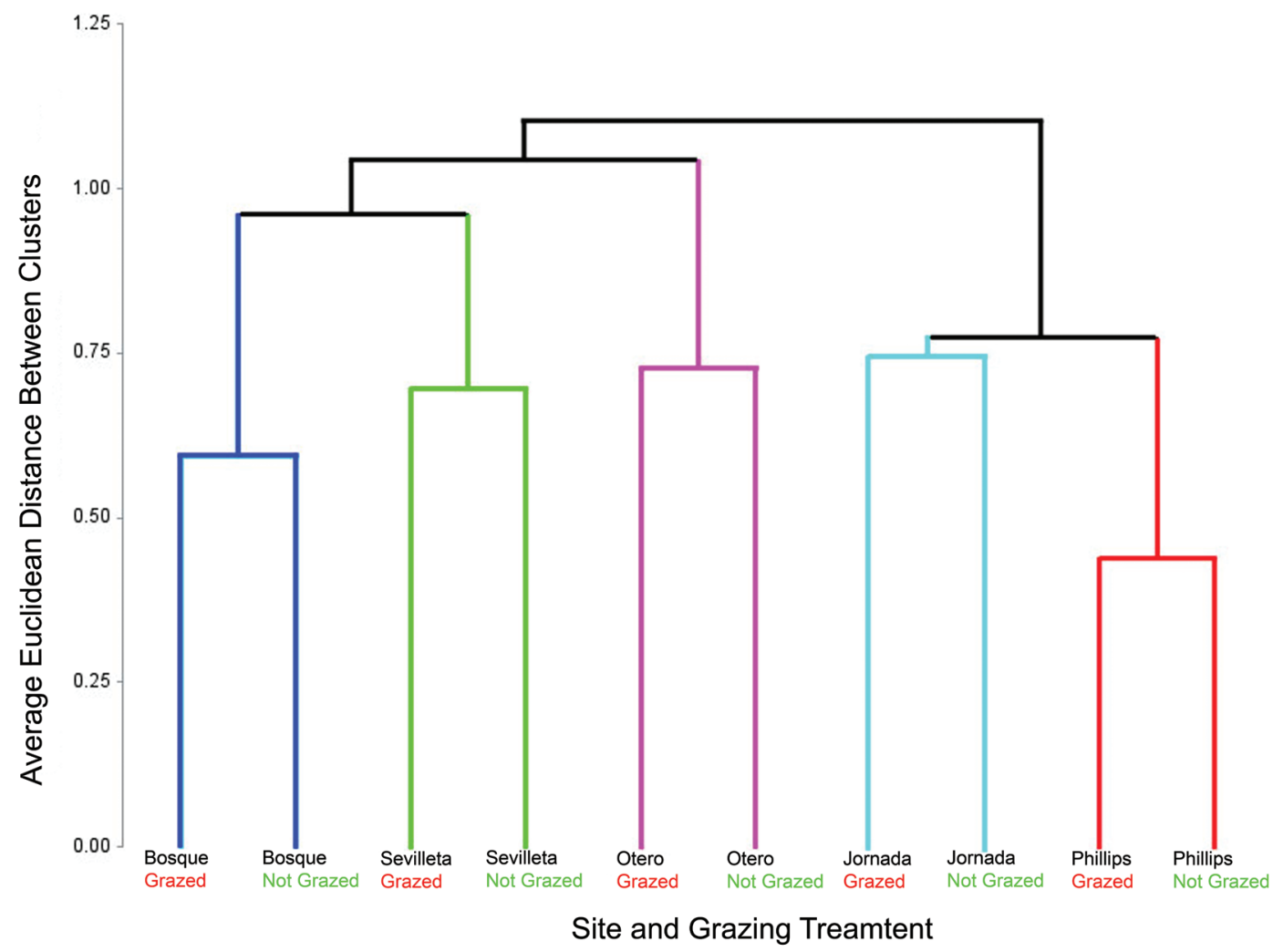

Fig. 3. Cluster analysis dendrogram showing the similarities of plant species compositions at sites and grazed and not grazed transects within sites, from annual canopy cover $/ \mathrm{m}^{2}$ averaged over all years and seasons; A. Spring; B. Fall. 
Table 3. Grasshopper species observed across the 5 study sites. Taxonomic classification and names follow Cigliano et al. (2017). Table is sorted in alphabetical order.

\begin{tabular}{|c|c|c|c|c|c|}
\hline Species & Family & Subfamily & Code & Life-form & Life history \\
\hline Ageneotettix deorum & Acrididae & Gomphocerinae & AGDE & TG & SU \\
\hline Arphia conspersa & Acrididae & Oedipodinae & ARCO & $\mathrm{T}$ & SP \\
\hline Arphia pseudonietana & Acrididae & Oedipodinae & ARPS & $\mathrm{T}$ & SU \\
\hline Aulocara elliotti & Acrididae & Gomphocerinae & AUEL & TG & SU \\
\hline Brachystola magna & Romaleidae & Romaleinae & BRMA & $\mathrm{H}$ & SU \\
\hline Campylacantha olivacea & Acrididae & Melanoplinae & CAOL & A & SU \\
\hline Cibolacris parviceps & Acrididae & Gomphocerinae & CIPA & $\mathrm{T}$ & SP \\
\hline Conozoa texana & Acrididae & Gomphocerinae & COTE & $\mathrm{T}$ & SU \\
\hline Cordillacris crenulata & Acrididae & Gomphocerinae & COCR & TG & SU \\
\hline Heliaula rufa & Acrididae & Gomphocerinae & HERU & $\mathrm{T}$ & SU \\
\hline Hesperotettix viridis & Acrididae & Melanoplinae & HEVI & A & SU \\
\hline Hippopedon capito & Acrididae & Oedipodinae & HICA & $\mathrm{T}$ & SU \\
\hline Hypochlora alba & Acrididae & Melanoplinae & HYAL & A & SU \\
\hline Lactista azteca & Acrididae & Oedipodinae & LAAZ & $\mathrm{T}$ & SU \\
\hline Leprus wheelerii & Acrididae & Oedipodinae & LEWH & $\mathrm{T}$ & SU \\
\hline Ligurotettix planum & Acrididae & Gomphocerinae & LIPL & A & SU \\
\hline Melanoplus regalis & Acrididae & Melanoplinae & MERE & $\mathrm{H}$ & SU \\
\hline Melanoplus aridus & Acrididae & Melanoplinae & MEAR & A & SU \\
\hline Melanoplus arizonae & Acrididae & Melanoplinae & MEAR2 & $\mathrm{H}$ & SU \\
\hline Melanoplus bowditchi & Acrididae & Melanoplinae & МЕBO & A & SU \\
\hline Mestobregma terricolor & Acrididae & Oedipodinae & METE2 & $\mathrm{T}$ & SU \\
\hline Opeia obscura & Acrididae & Gomphocerinae & ОРОВ & G & SU \\
\hline Paropomala pallida & Acrididae & Gomphocerinae & PAPA & G & SU \\
\hline Phlibostroma quadrimaculatum & Acrididae & Gomphocerinae & PHQU & TG & SU \\
\hline Phrynotettix robustus & Romaleidae & Romaleinae & PHRO & $\mathrm{T}$ & SP \\
\hline Psoloessa delicatula & Acrididae & Gomphocerinae & PSDE & TG & SP \\
\hline Psoloessa texana & Acrididae & Gomphocerinae & PSTE & TG & SP \\
\hline Schistocerca nitens & Acrididae & Cyrtacanthacridinae & SCNI & A & SU \\
\hline Syrbula montezuma & Acrididae & Gomphocerinae & SYMO & G & SU \\
\hline Trachyrhachys aspera & Acrididae & Oedipodinae & TRAS & $\mathrm{T}$ & SU \\
\hline Trachyrhachys kiowa & Acrididae & Oedipodinae & TRKI & $\mathrm{T}$ & SU \\
\hline Trimerotropis californica & Acrididae & Oedipodinae & TRCA & $\mathrm{T}$ & SU \\
\hline Trimerotropis pallidipennis & Acrididae & Oedipodinae & TRPA & $\mathrm{T}$ & SP, SU \\
\hline Trimerotropis pistrinaria & Acrididae & Oedipodinae & TRPI & $\mathrm{T}$ & SU \\
\hline Trimerotropis latifasciata & Acrididae & Oedipodinae & TRLA & $\mathrm{T}$ & SU \\
\hline Tropidolophus formosus & Acrididae & Oedipodinae & TRFO & $\mathrm{H}$ & SU \\
\hline Xanthippus corallipes & Acrididae & Oedipodinae & XACO & $\mathrm{T}$ & SP \\
\hline Xanthippus montanus & Acrididae & Oedipodinae & XAMO & $\mathrm{T}$ & SP \\
\hline
\end{tabular}

${ }^{*}$ Life-form codes: $\mathrm{A}=$ arbusticole, $\mathrm{G}=$ graminicole, $\mathrm{TG}=$ terri-graminicole, $\mathrm{H}=$ herbicole, $\mathrm{T}=$ terricole.

** Life history codes: $\mathrm{SP}=$ spring/early summer, $\mathrm{SU}=$ late summer/fall. 

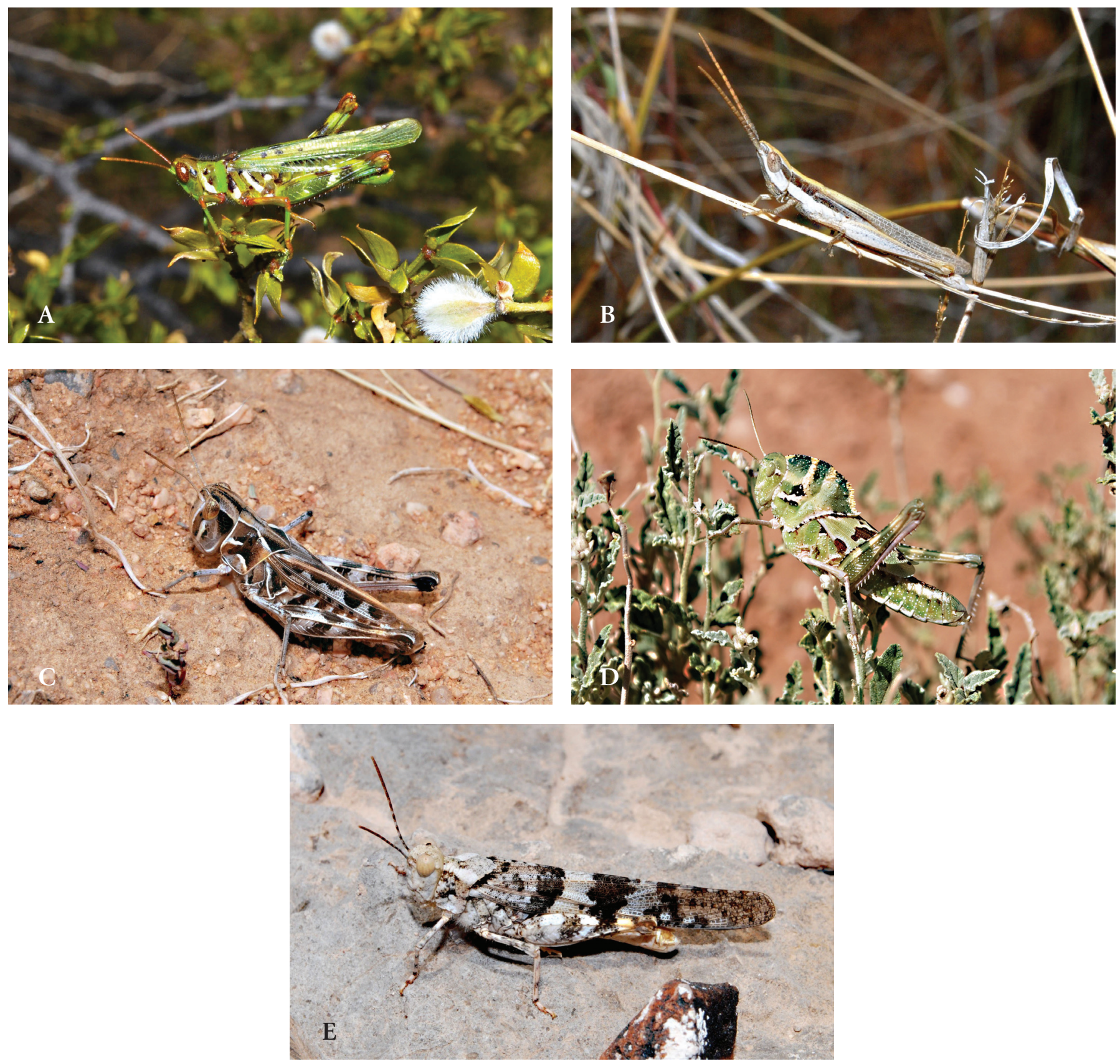

Fig. 4. Examples of each grasshopper life-form type; A. Arbusticole; Bootettix argentatus on Larrea tridentata; B. Graminicole; Paropomala pallida on Bouteloua eriopoda; C. Terri-graminicole; Phlibostroma quadrimaculatum; D. Herbicole; Tropidolophus formosus on Spharalcea hastulata; E. Terricole; Trimerotropis pallidipennis.

for cluster analysis to evaluate similarities of substrate use across all grasshopper species. Based on morphology and substrate use, the resulting life-form guild terricoles, were the largest life-form group with 20 species, followed by 11 herbicoles, 8 arbusticoles, and 7 graminicoles (Table 3). Additionally, a group of species (Ageneotettix deorum, Aulocara spp., Cordillacris spp., Phlibostroma quadrimaculatum, Psoloessa spp.) used bare soil and low-growing grasses as their substrates, and had morphologies intermediate between graminicoles and terricoles. Uvarov (1977) called such intermediate life-forms terri-graminicoles, and I categorized those 8 species as terri-graminicoles: species that use both bare soil and low stature grasses as microhabitat substrates, and are known to feed largely on grasses. Examples of grasshopper life-forms represented by species observed in this study are presented in Fig. 4. Note that the determination of a species' substrate use in this study is relative to the number of observations made for each species; determinations for species with many observations are more likely to reflect the species actual substrate uses more accurately than for species with few observations (see Suppl. material 3 and Suppl. material 4).

Examination of the morphology of each species relative to Uvarov's (1977) life-form descriptions revealed high correspondence between substrate use groupings and life-form morphologies, except for some grasshopper species in the subfamily Melanopli- 


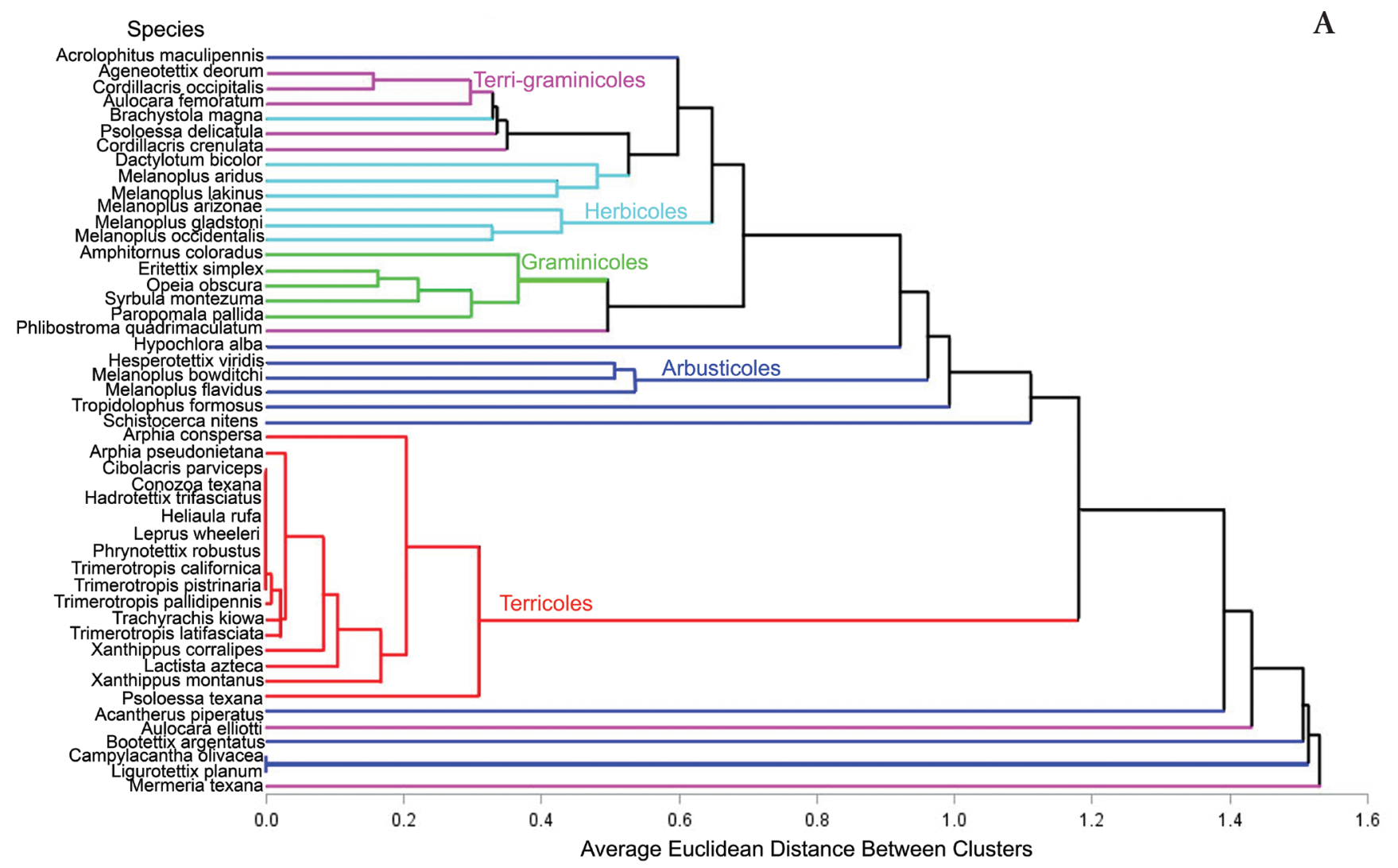

Average Euclidean Distance Between Clusters

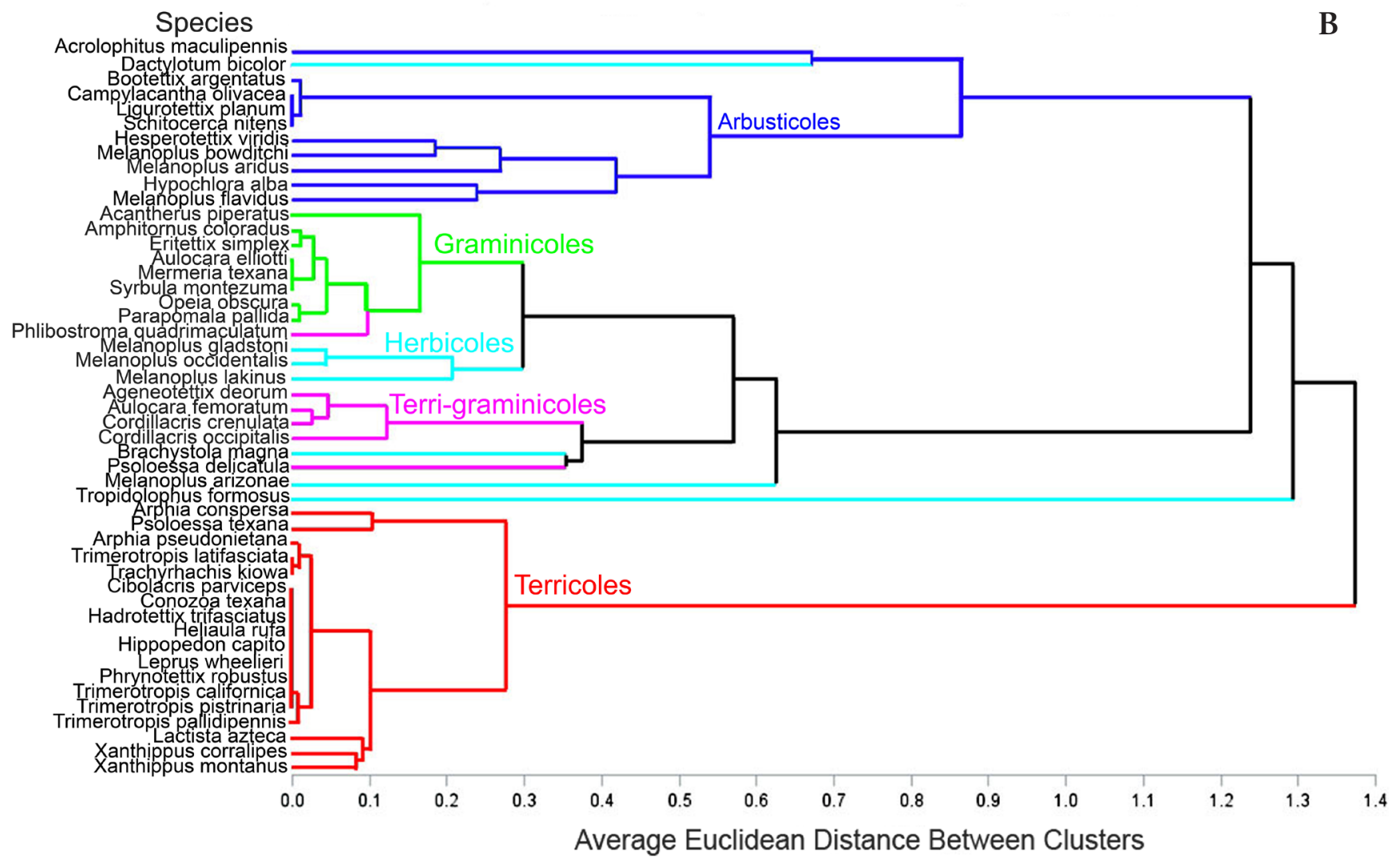

Fig. 5. Cluster analysis dendrograms of grasshopper species similarities based on substrate use among all grasshopper species over all sites, years and seasons; A. Based on specific substrate use to the plant species level and bare soil; B. Based on substrates categorized to forbs, grasses, shrubs and bare soil. 
nae, which separated into both herbicoles and arbusticoles based on substrate use, while sharing similar ecomorphologies (Suppl. material 4). Some species that had herbicole life-form morphologies used shrubs (e.g. Campylacantha olivacea, Hypochlora alba, Melanoplus aridus, M. bowditchi, and M. flavidus), while others such as Brachystola magna and M. arizonae used forb, grass, and soil substrates. Tropidolophus formosus had the morphology of a herbicole but was distinct from other herbicoles based on primary substrate use of Spharalcea species forbs. Acantherus piperatus had the morphology of a graminicole, and occurred primarily on bush muhly grass, which grew inside of shrub canopies, and individuals often rested on shrub branches mixed with bush muhly. Acrolophitus maculipennis (Gomphocerinae) was associated primarily with the small shrub, hairy crinkle mat (Tiquilia hispidissima), and individuals were usually on their host plants, but also often on bare rocky gypsum soil in association with hairy crinkle mat plants. Overall substrate use did correspond well with grasshopper species lifeform guild morphologies for most grasshopper species.

Cluster analysis of each grasshopper species based on observed specific substrate use by all individuals of each grasshopper species, over all five sites and all five years, revealed distinct groupings of species based on specific observed substrate use (Fig. 5A). Arbusticoles that were host plant specific, such as Bootettix argentatus, Campylacantha olivacea, Ligurotettix planum, Hypochlora alba, Melanoplus bowditchi, Melanoplus flavidus, Schistocerca nitens and Hesperotettix viridis were distinct from all other species. Terricoles such as Arphia spp., Cibolacris parviceps, Conozoa texana, Hadrotettix trifasciatus, Heliaula rufa, Hippopedon capito, Leprus wheelerii, Phrynotettix robustus, Lactista azteca, Psoloessa texana, Trimerotropis spp. Trachyrhachys kiowa, and Xanthippus spp., formed a large distinct group. Graminicoles such as Amphitornus coloradus, Eritettix simplex, Syrbula montezuma, Opeia obscura and Paropomala pallida grouped together. Terri-graminicoles such as Ageneotettix deorum, Cordillacris spp., Aulocara femoratum, and Psoloessa delicatula, grouped together, and all had mandible morphologies of grassfeeders. Herbicoles such as Dactylotum bicolor and all Melanoplus spp., except M. bowditchi and M. flavidus, grouped together.

I further examined the relationships between grasshopper life-forms, plant-life forms, and bare soil, by performing a second cluster analysis of observed grasshopper species substrate use, with plant species specific substrates pooled into the plant life-form categories instead of plant species; forbs, grasses or shrubs, along with bare soil. The resulting dendrogram (Fig. 5B) revealed similar but more pronounced substrate category use groupings to Fig. 5A. Arbusticole and herbicole grasshoppers formed more pronounced groups rather than separating as disparate species in Fig. 5A. All arbusticoles grouped together with the herbicole Dactylotum bicolor, which was observed on forbs, soil and shrubs. All graminicoles grouped together along with the terri-gramincole Phlibostroma quadrimaculatum and the herbicoles Melanoplus gladstoni, M. occidentalis, and M. lakinus, all of which were usually on forbs but also on grasses. The terri-graminicoles grouped together with the herbicole Brachystola magna which occurred on forbs, grasses and bare soil. Terricoles grouped together in a distinct cluster from all other clusters. One herbicole species, Tropidolophus formosus, did not group with any other herbicoles due to its primary association with forbs in the genus Spharalcea.

Spearman rank correlation analysis compared the total numbers of individual grasshoppers observed across all species, and assigned to grasshopper life-forms, with available plant life-form and bare soil cover measured from $1 \mathrm{~m}^{2}$ quadrats and averaged over all sites, transects, years and seasons. Correlation analysis
Table 4. Spearman-rank correlation coefficients $\left(r_{s}\right)$ and significance values (P) from testing relationships between grasshopper life-forms and the available cover of substrate categories measured on the grasshopper and vegetation transects at each study site, over all years and seasons. Correlation coefficients are listed first, above significance values within each life-form by substrate set of cells. Significant $(\mathrm{P}<0.05)$ correlations are in bold text, positive correlations are in regular font and negative correlations are in italic font. Sample size for all tests was 96 .

\begin{tabular}{lcccc}
\hline & \multicolumn{4}{c}{ Substrate Categories } \\
\hline Grasshopper life-forms & Bare Soil & Grasses & Forbs & Shrubs \\
Arbusticoles & -0.24058 & -0.24703 & 0.14819 & 0.61254 \\
& 0.0182 & 0.0153 & 0.1496 & $<.0001$ \\
Graminicoles & -0.31407 & $\mathbf{0 . 5 7 6 8 2}$ & 0.12125 & -0.26054 \\
& 0.0018 & $<.0001$ & 0.2393 & 0.0104 \\
Terri-graminicoles & 0.13191 & $\mathbf{0 . 4 7 3 2 8}$ & -0.1248 & -0.57136 \\
& 0.2002 & $<.0001$ & 0.2257 & $<.0001$ \\
Herbicoles & -0.13658 & $\mathbf{0 . 2 3 1 2 9}$ & $\mathbf{0 . 3 8 2 7 9}$ & -0.26019 \\
& 0.1845 & $\mathbf{0 . 0 2 3 4}$ & $\mathbf{0 . 0 0 0 1}$ & 0.0105 \\
Terricoles & -0.28696 & $\mathbf{0 . 4 4 6 0 1}$ & 0.17449 & -0.18596 \\
& 0.0046 & $<.0001$ & 0.0891 & 0.0697 \\
\hline
\end{tabular}

revealed significant relationships between grasshopper life-forms and substrate availability (Table 4). Arbusticoles were positively correlated with shrub canopy cover, while they were negatively correlated with bare soil and grass cover. Graminicoles were positively correlated with grass cover, and negatively correlated with bare soil and shrub cover. Terri-graminicoles were positively correlated with grass cover, and negatively correlated with shrub cover. Herbicoles were positively correlated with both forb and grass cover, and negatively correlated with shrub cover. However, terricoles were positively correlated with available grass cover, and negatively correlated with available bare soil.

Cluster analysis of grazed vs. non-grazed sites in the spring and in the fall over all years revealed that, like vegetation, grasshopper species assemblages were unique to each site. Branch lengths in the dendrograms were not as long as for plant assemblages, demonstrating the site to site variation and differences in grazed vs. non-grazed in grasshopper assemblages was less than it was for plant assemblages (Fig. 3 vs. Fig. 6). Grasshopper species assemblages at the Bosque, Jornada and Phillips sites were more similar to each other than species assemblages at the Otero and Sevilleta sites (Fig. 6). The Otero site grazed area was unique from all other sites/treatments, in both spring and fall seasons. Grasshopper species richness ranged from about five species to about 20 species across the study sites, years and seasons. Overall grasshopper species richness generally ranged from five to 15 species at each site over the five-year period, averaging around 10 species at any given time, and more grasshopper species were typically present in the fall than in the spring of each year (Suppl. material 1: Fig. S3). The Jornada and Otero sites generally had the most grasshopper species, followed by the Bosque and Phillips sites. The grazed areas tended to support less grasshopper species than the non-grazed areas at all five sites over the five-year period, but that pattern was inconsistent (Suppl. material 1: Fig. S3). Overall, the non-grazed sides of the fences across all sites, years and seasons tended to support the highest grasshopper species richness.

Analysis of the grasshopper life-form guilds revealed that livestock grazing primarily affected graminicoles and terri-gramini- 

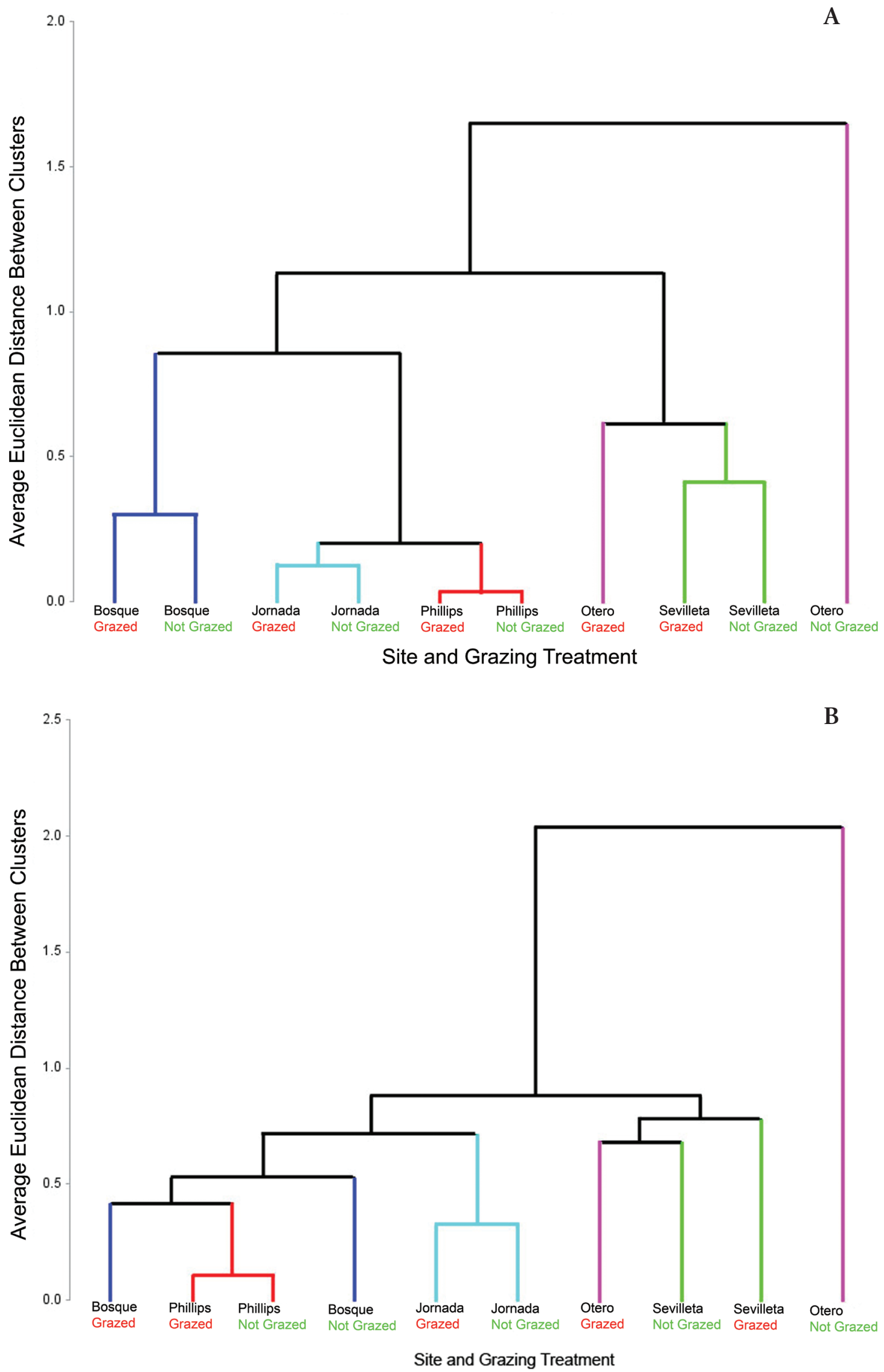

Fig. 6. Cluster analysis dendrograms showing site and grazing treatment similarities of grasshopper species compositions; A. Spring; B. Fall. 
coles, which tended to be significantly more abundant on nongrazed than grazed areas, and especially at the Bosque, Otero, and Sevilleta sites, both in the spring and in the fall seasons (Suppl. material 1: Fig. S4, Suppl. material 2: Table S5). That pattern was especially pronounced in high precipitation years with high grasshopper abundance. Herbicoles followed a similar but less pronounced pattern of greater abundance on non-grazed sides of the fences across the same sites, especially in wet years. In contrast, terricoles tended to be significantly more abundant on grazed areas than non-grazed areas at the same sites and years as graminicoles and terri-graminicoles were more abundant on the non-grazed sides of the fences (Suppl. material 1: Fig. S4, Suppl. material 2: Table S5). Arbusticoles were generally less abundant than other grasshopper guilds, and were significantly more abundant on the nongrazed area at the Bosque site in fall 1993, but significantly more abundant on the grazed area at the Jornada site in fall of 1992 and 1993 (Suppl. material 2: Table S5, Suppl. material 1: Fig. S4).

Arbusticoles were mostly associated with one or a few species of perennial woody shrubs. Bootettix argentatus (Gomphocerinae) was associated only with creosote bush at the Jornada, Otero, and rarely at the Phillips sites. Campylacantha olivacea (Melanoplinae) and Ligurotettix planum (Gomphocerinae) were found only on tarbush (Flourensia cernua) at the Jornada and the Phillips sites, and Hesperotettix viridis (Melanoplinae) was only associated with broom snakeweed across the sites. Hypochlora alba (Melanoplinae) was associated primarily with sand sage (Artemisia filifolia), but also some forbs at the Bosque site (Suppl. material 3, Suppl. material 4). Melanoplus aridus and M. bowditchi (Melanoplinae) were associated primarily with shrubs in the family Asteraceae at the Jornada and Phillips sites, and Schistocerca nitens (Cyrtacanthacridinae) was associated with honey mesquite and tarbush shrubs at the Jornada site. Arbusticoles were consistently associated with woody shrubs, usually one or a few species of shrubs, but the grasshopper species belonged to different subfamilies.

The most abundant graminicoles were species in the subfamily Gomphocerinae; Paropomala pallida which was highly associated with black grama grass on the non-grazed side of the fences at the Bosque, Otero and Sevilleta sites, and less associated with bush muhly grass along with Acantherus piperatus, at the Jornada and Phillips sites, and Eritettix simplex and Opeia obscura that tended to be associated with galleta and tabosa grasses (Pleuraphis spp.) and burro grass (Sceropogon brevifolius) across all of the sites (Suppl. material 3, Suppl. material 4). Graminicoles all belonged to the same subfamily, and all were associated with grasses, but different species were associated with different grass species, and most species were most abundant on the non-grazed areas at the Bosque, Otero, and Sevilleta sites.

Abundant terri-graminicoles also were mostly in the subfamily Gomphocerinae; including Aulocara femoratum, Cordillacris occipitalis, Ageneotettix deorum, and Phlibostroma quadrimaculatum that were associated with blue grama and burrow grasses at the Otero and Sevilleta sites in the fall. Psoloessa delicatula was a terri-graminicole associated with fine soils and grasses at the Sevilleta, Bosque and Otero sites, while P. texana was a terricole associated with coarse gravelly soils at the Jornada and Phillips sites (Suppl. material 3, Suppl. material 4). Like graminicoles, terri-graminicoles were associated with grasses, but all were most associated with low-profile perennial grasses such as blue grama and burro grass.

The most abundant herbicoles were species in the family Melanoplinae; the fall species Melanoplus arizonae, M. lakinus, and M. gladstoni at the Otero and Sevilleta sites, M. flavidus at the Bosque site, and M. aridus at the Jornada and Phillips sites (Table S3, Table S4). Most herbicoles were melanoplines associated with a variety of plant species, but included Brachystola magna (Romaleidae) a generalist, and Tropidolophus formosus (Oedipodinae) a plant specialist which was associated with mallows (Spharalcea spp.: Malvaceae). As stated above, Melanoplinae had the ecomorphologies of herbicoles, but also were common on grasses, bare soils, and some on shrubs.

Terricoles were mostly in the subfamily Oedipodinae; the most abundant terricole was Trimerotropis pallidipennis across all sites and years, especially in the fall of 1995 and 1996 at the Sevilleta site, and T. pallidipennis was represented by two cohorts each year, one in the spring, and another in the fall; the spring cohort was affected positively by the El Niño event in 1992 and the fall cohort by the La Niña event in 1996 (Table S3). Other abundant terricoles included Trachyrhachys kiowa, Trimerotropis californica, and Arphia pseudonietana in the fall, and Psoloessa texana, Xanthippus corallipes and Arphia conspersa in the spring. The common terricole Cibolacris parviceps belonged to the subfamily Gomphocerinae, and the rare terricole Phrynotettix robustus to the family Romaleidae: Romaleinae. Most terricole species appeared to be more closely associated with specific soil surface types - clay, silt, sand, gravel - than to any particular plant species.

\section{Discussion}

The findings from this study demonstrate that short-term domestic cattle grazing and short-term climate variation did affect the species and life-form compositions and foliage canopy cover and height of vegetation, and the species and life-form guild compositions and abundances of grasshopper communities across a series of five study sites over five years. Grazing effects on vegetation and grasshoppers were significant during years with high rainfall, plant production and grasshopper abundance, but not years when rainfall, plant production and grasshopper abundance were all low. These results were similar to the findings of other research in North America (Jepsen-Innes and Bock 1989, Quinn and Walgenbach 1990, Fielding and Brusven 1993, 1995, Jones 2006), in Africa (Prendini et al. 1996, Gebeyehu and Samways 2003 ) and in China (Kang and Chen 2008). Grasshoppers in this study responded to grazing much as Fielding and Brusven (1996) reported for grasshopper communities from similar semi-arid desert grasslands and shrublands elsewhere in North America. Shortterm livestock grazing reduced perennial grass cover and heights, increased annual grasses following periods of increased rainfall, and enhanced populations of terricole grasshopper species (reported as Oedipodinae by Fielding and Brusven 1996). This study demonstrates that short-term livestock grazing did alter the vegetation and grasshopper species and life-form compositions, annual variation in precipitation did interact with grazing to affect both plant and grasshopper species assemblages and grasshopper guild structure, and terricole, terri-graminicole, graminicole and herbicole grasshopper life-form guilds and their most abundant component species were most sensitive to livestock grazing and climate variation, while arbusticoles were not. The effects of livestock grazing on vegetation and grasshoppers were significant during an El Niño event in 1992 that produced high winter and spring rainfall, and during a La Niña event in 1996 that produced high summer rainfall, each affecting vegetation and grasshoppers differently during those different seasons.

The effects of livestock grazing on grasshoppers in this study were more pronounced in desert grassland environments than in 
desert shrubland environments. The Bosque, Otero and Sevilleta sites were desert grassland or shrub steppe and supported relatively high perennial grass cover on the non-grazed sides of the fences. The Jornada and Phillips sites were creosote bush shrublands, and most of the perennial grass at those sites was bush muhly which grew within the shrub canopies, while the soil surfaces between shrubs were primarily bare and gravelly. Livestock grazing at the desert grassland sites reduced the canopy cover and heights of perennial grasses on the grazed sides of the fences, while relatively higher perennial grass cover and canopy heights were present on the non-grazed sides of the fences. In spring 1992 and in fall 1996 grasshopper densities were high, and terricoles and terri-graminicoles were abundant along with annual grasses and forbs on the more open bare grazed fence sides, while graminicoles were more abundant on the denser perennial grasses on the non-grazed sides of the fences. Arbusticoles showed relatively little response to livestock grazing, because the perennial shrubs that they lived and fed on also did not change much over the five-year period.

Climate variation resulting primarily from opposing ENSO events over a five-year period further interacted with livestock grazing to amplify or reduce the effects of livestock grazing on vegetation and grasshoppers. Increased winter and spring precipitation from an El Niño event in 1992 positively affected both annual herbaceous vegetation and grasshoppers in the spring of 1992 and 1993, more so on grazed areas than non-grazed areas. The La Niña event of 1996 positively affected annual herbaceous vegetation and grasshoppers in the late summer of 1996, but not in the spring of that year, and that effect was more pronounced on grazed lands than non-grazed lands. Grasshopper responses to annual and season variation in precipitation were similar to the findings of Edwards (1960), Gage and Mukerji (1977), Begon (1983), Capinera and Horton (1989) and Fielding and Brusven (1990). While Jonas and Joern (2007) emphasized the importance of both the previous year's grasshopper population densities and winter precipitation on subsequent populations, the five-year temporal data from this study were not extensive enough nor partitioned into small enough periods to determine if time-lag effects were present, or how such lag effects may have resulted from previous grasshopper density and environmental conditions. Fielding and Brusven (1996) found that over a 27 year period, the previous November precipitation and mean April temperatures were the best predictors of variation in annual grasshopper densities, while cold winter temperatures reduced grasshopper densities. These findings all indicate that ongoing climate change will likely influence the interactive dynamics of grasshoppers, vegetation, livestock grazing and weather.

Grasshopper species and life-form guilds that were affected positively by livestock grazing and climate variation were those that preferred bare soil microhabitats, and also responded to increases in rainfall and annual forb and grass production on bare soils disturbed by livestock. Oedipodinae and Gomphocerinae species that tend to be terricole or terri-graminicole species also tend to be mixed grass and forb feeders with relatively broad diets (Mulkern 1967, Uvarov 1977, Joern 1985, Chapman 1990). Fielding and Brusven (1996) discussed how substrate matching camouflage is important for many grasshopper species, especially Oedipodinae that live on bare soils (i.e. terricoles), and that reduced vegetation cover from grazing favors such ground-dwelling terricole grasshopper species. Capinera and Sechrist (1982) also found that Oedipodinae (i.e. terricoles), were most abundant in heavily grazed areas compared to lightly grazed areas in short-grass prairie.

In this study, terricoles that preferred bare soil tended to show the greatest responses to increased production of annual herba- ceous vegetation in disturbed grazed areas that also had bare soil substrates, especially Trimerotropis pallidipennis, Trimerotropis californica, and Trachyrachis kiowa. Although terricoles used bare soil surfaces almost exclusively as substrates, and are known to utilize bare ground as a microhabitat, correlation analysis revealed that they were negatively associated with available bare ground across locations, years and seasons, but were positively correlated with spatially and temporally variable annual grass cover. These results indicate that while terricoles require long-term availability of bare soil for a microhabitat substrate, over time and space, their densities vary positively over the short-term with the availability of annual grass and forb canopy cover as a food resource.

Terri-graminicoles also preferred microhabitats with sparse, low-growing grasses such as blue grama and burro grass, and spent much of their time on bare ground substrates (bare soil), and responded to increases in grasses as correlation analysis revealed. Those terri-graminicoles included the Gomphocerinae species Aulocara femoratum, Ageneotettix deorum, Psoloessa delicatula, Psoloessa texana, Cordillacris occipitalis and Phlibostroma quadrimaculatum, most of which were more abundant on the grazed sides of fencelines, but primarily at the Otero and Sevilleta sites that had short and patchy perennial grasses like blue grama and burrow grass. Quinn and Walgenbach (1990) also found that some of the same Gomphocerinae grasshopper species were more abundant in grazed areas with more bare soil and short sparse grasses, where those species were better camouflaged from predators. Also similar to these findings, Prendini et al. (1996) found grasshopper species in savanna environments that preferred sparse and low-profile vegetation were more abundant in heavily grazed areas, while those species that preferred tall and dense grass more abundant in non-grazed and lightly grazed areas.

Graminicoles were affected negatively by livestock grazing, apparently due to the reduced cover and heights of the perennial grasses that they lived and fed on, which were often significantly taller and had greater canopy cover on the non-grazed sides of fencelines at the grasslands Sevilleta and Otero sites. Graminicoles increased with increased rainfall and perennial grass production which occurred mostly in non-grazed areas where perennial grass cover was higher and not affected by current livestock grazing. Graminicoles primarily used grass plants as substrates, and were positively correlated only to available grass canopy cover over space and time. Common graminicoles such as Paropomala pallida and Acantherus piperatus were highly associated with black grama and bush muhly grasses respectively, which experienced reduced canopy cover when grazed, and increased canopy cover and height under high precipitation conditions. Other graminicoles appeared to be less associated with particular grass species, but Eritettix simplex, Amphitornus coloradus, Syrbula montezuma and Opeia obscura were associated with dense, tall perennial grasses that provided adequate structural microhabitats in ungrazed areas, compared to structurally less robust annual grasses (e.g. sixweeks threeawn) that dominated grazed areas. Unlike terri-graminicoles that also feed on and are associated with grasses, but are adapted to live on bare soil, graminicoles have morphological adaptations (elongate bodies and antennae and short legs with grasping tarsi and arolia and camouflage patterns and colors) for living on the stems and leaves of tall dense grasses as resting and feeding substrates (Uvarov 1977, Lightfoot 1985).

Herbicoles were composed largely of Melanoplinae, including several species of Melanoplus, and most appeared to be host-plant generalists except for the oedipodine Tropidolophus formosus that specialized on Spharalcea plants. Many of the common Melanoplus 
such as $M$. arizonae, M. lakinus and $M$. sanguinipes are known to have broad diets and have not evolved to specialize on any particular plants. Such generalization on leafy forbs may be attributed to low plant apparency in space and time, and the diversity of acutely toxic plant secondary chemical defenses such as flavonoids and glycosides that limit herbivores from specializing on those plants as food resources (Otte 1976, Otte and Joern 1977, Chapman 1990). Other research also has shown that melanoplines tend to have broad diets and are ecological generalists, especially agricultural pest species such as $M$. sanguinipes. Such generalist species also tend to have dynamic populations that vary considerably with weather and plant production (Fielding and Brusven 1990, Jonas and Joern 2007). In this study herbicoles did increase with increased rainfall and plant production, however the increases occurred both under grazed and non-grazed areas, apparently overriding grazing effects alone.

The arbusticoles also were strongly associated with plants, not soil; all were host-shrub specific species except for the shrub generalist Schistocerca nitens. Each arbusticole species was strictly associated with its host shrub species, and unlike the other grasshopper guilds that shared grasshopper species across sites, arbusticoles tended to be site-specific based on shrub species distributions. Bootettix argentatus only occurred at the Jornada, Otero and Phillips sites where creosote bush was present, and was not affected by grazing. Campylacantha olivacea and Ligurotettix planum were restricted to tarbush, which only occurred at those same three sites, while Hypochlora alba was restricted to sand sage at the Bosque site, the only site where sand sage occurred, along with the more generalist Melanoplus flavidus. Broom snakeweed occurred at all sites, and supported not only Hesperotettix viridis which is monophagous on broom snakeweed, but also Melanoplus bowditchi and M. aridus which occurred on a variety of shrubs in the plant family Asteraceae. While terricoles, terri-graminicoles and graminicoles were more closely associated with the microhabitat structure than particular plant species, arbusticoles also were associated with particular plant microhabitats, but those present on particular shrub species with particular morphologies and chemistries. For example Bootettix argentatus is a leaf and small stem mimic of cresosote bush foliage, and Ligurotettix planum is a stem mimic on tarbush. Each shrub species also has unique foliage chemistry, apparently driving the evolution of monophagy in arbusticoles as the result of plant apparency and the evolution of specialization on highly apparent host plants with different secondary plant chemistries and different substrates for camouflage from predators (Otte 1976, Otte and Joern 1977, Chapman 1990).

The application of life-form guilds as grasshopper indicators to environmental change has world-wide utility and allows for global comparisons of grasshopper life-form guild structure across continents in relation to landscape features and ecological patterns and processes. As with any attempt by humans to classify species into ecological categories, not all species fit well into grasshopper life-form guilds such as some mentioned above. However, most grasshopper species addressed in this study did correspond to particular life-form guilds, or some combination of more than one guild (e.g. terri-graminicoles). Based on these findings, the grasshopper life-form guild concept does have merit for understanding resource use and structure of semi-arid and arid environment grasshopper communities.

Livestock grazing is prevalent and often ecologically unsustainable across semi-arid regions around the world, as is desertification, the long-term result of unsustainable livestock grazing (Dregne 1986, Nelson 1988). Based on the findings of this study, one may assume that the desertified semi-arid landscapes of the world, and those studied here, now have different grasshopper community compositions than they did prior to desertification. Desertified landscapes that were formerly dominated by relatively stable desert grasslands, and likely corresponding graminicoles and terri-graminicoles, are likely now dominated by shrublands, and/or bare soil, and annual grasses and forbs that fluctuate with rainfall. Such desertified landscapes also are likely now dominated by terricoles, arbusticoles and herbicoles as in this study. As landscape vegetation changes, so too should the grasshopper species and life-form guild compositions and associated diets and resource uses. Shifts in grasshopper community life-form guild compositions also should have cascading effects on ecosystem processes such as energy flow and nutrient cycling. If desert grasslands shift from a dominance of perennial grass and grass-feeding graminicoles, to a dominance of annual grasses and forbs, woody shrubs, and mixed-diet terricoles, herbicoles and plant specific arbusticoles, the consumer roles of grasshoppers feeding on those different types of plants should also shift. Additionally, a number of independent research studies have demonstrated that soil and vegetation disturbance caused by heavy livestock grazing in semi-arid regions of North America leads to ecological instability and outbreaks of ecological generalist agricultural pest grasshopper species such as Melanoplus sanguinipes (Padft 1982, Quinn and Walgenbach 1990, Fielding and Brusven 1995b, 1996, Rambo and Faeth 1999, and Debano 2006). This same pattern may occur globally in other systems with other grasshopper pest species.

Given the global extent of semi-arid landscapes that have been and continue to be negatively impacted by livestock grazing (see Introduction), understanding the effects of grazing on vegetation and grasshoppers is key to understanding how to manage natural resources of such lands (Laycock 1994). Such knowledge of changes to grasshopper community composition and structure will contribute to guiding better management of the natural resources on desertified landscapes (e.g. Peters et al. 2015). Anthropogenic climate change is a serious environmental issue globally, and increasing global temperatures and increasing variation and reductions in precipitation across semi-arid regions is intensifying the negative effects of livestock grazing on soils, native plants and native animals. More research like this study is needed on a global-scale to better understand how livestock grazing and climate change are interacting in different world regions with different environments, plant and grasshopper species, human cultures and associated natural resource uses.

\section{Acknowledgements}

The U.S. Department of Interior, Bureau of Land Management, funded this research as part of the BLM Global Change Research Projects Program, the Chihuhuhan Desert Subproject. Laura F. Heunneke (then of New Mexico State University, presently at Northern Arizona University) was instrumental in obtaining the funding for this research and assisted in study site selection. A special thank you to Karen S. Lightfoot for assisting me in the field and with manuscript preparation. Thank you anonymous reviewers for improving this manuscript. The Museum of Southwestern Biology, Biology Department, University of New Mexico, provided resources for me to work on this project.

\section{References}

Anderson NL (1964) Some relationships between grasshoppers and vegetation. Annals of the Entomological Society of America 57: 736-742. https://doi.org/10.1093/aesa/57.6.736 
Archer S (1994) Woody plant encroachment into Southwestern grasslands and savannas: Rates, patterns and proximate causes. In: Vavra M, Laycock WA, Pieper RD (Eds) Ecological implications of livestock herbivory in the West. Society for Range Management, Denver, CO, 13-68.

Bazelet CS, Samways MJ (2011) Identifying grasshopper bioindicators for habitat quality assessment of ecological networks. Ecological Indicators 11: 1259-1269. https://doi.org/10.1016/j.ecolind.2011.01.005

Begon M (1983) Grasshopper populations and weather: The effects of insolation on Chorthippus brunneus. Ecological Entomology 8: 361-370. https://doi.org/10.1111/j.1365-2311.1983.tb00516.x

Belovsky GE, Joern A (1995) The dominance of different regulating factors for rangeland grasshoppers. In: Cappuccino N, Price P (Eds) Population Dynamics: New Approaches and Synthesis. Academic Press, New York, NY, 359-386. https://doi.org/10.1016/B978-012159270-7/50019-1

Branson DH, Sword GA (2010) An experimental analysis of grasshopper community responses to fire and livestock grazing in a northern mixed-grass prairie. Environmental Entomology 39: 1441-1446. https://doi.org/10.1603/EN09378

Buffington LC, Herbel CH (1965) Vegetational changes on a semi-desert grassland range from 1858-1963. Ecological Monographs 35: 139164. https://doi.org/10.2307/1948415

Capinera JE, Sechrist TS (1982) Grasshopper host plant associations: Response of grasshopper populations to cattle grazing intensity. Canadian Entomologist 114: 1055-1062. https://doi.org/10.4039/Ent1141055-11

Capinera JC (1987) Population ecology of rangeland grasshoppers. In: Capinera JC (Ed.) Integrated pest management on rangeland: a shortgrass perspective. Westview Press, Boulder, CO, 162-182.

Capinera JL, Horton DR (1989) Geographic variation in effects of weather on grasshopper infestation. Environmental Entomology 18: 8-14. https://doi.org/10.1093/ee/18.1.8

Chapman RF (1990) Food selection. In: Chapman RF, Joern A (Eds) Biology of grasshoppers. John Wiley and Sons, New York, NY, 39-72.

Cigliano MM, Torrusio S, De Wysiecki ML (2010) Grasshopper (Orthoptera: Acrididae) community composition and temporal variation in the Pampas, Argentina. Journal of Orthoptera Research 11: 215-221. https://doi.org/10.1665/1082-6467(2002)011[0215:GOACCA]2.0.CO;2

Cigliano MM, Braun H, Eades DC, Otte D (2017) Orthoptera species file online. http://orthoptera.speciesfile.org/HomePage.aspx [Accesssed: June 5, 2017]

Davidson AD, Lightfoot DC (2008) Burrowing rodents increase landscape heterogeneity in a desert grassland. Journal of Arid Environments 72: 1133-1145. https://doi.org/10.1016/j.jaridenv.2007.12.015

Davidson AD, Ponce E, Lightfoot DC, Fredrickson EL, Brown JH, Cruzado J, Brantley SL, Sierra-Corona R, List R, Toledo D, Ceballos G (2010) Rapid response of a grassland ecosystem to an experimental manipulation of a keystone rodent and domestic livestock. Ecology 91: 31893200. https://doi.org/10.1890/09-1277.1

Debano SJ (2006) Effects of livestock grazing on aboveground insect communities in semi-arid grasslands of southeastern Arizona. Biodiversity and Conservation 15: 2547-2564. https://doi.org/10.1007/ s10531-005-2786-9

Dempster JP (1963) The population dynamics of grasshoppers and locusts. Biological Review 38: 490-529. https://doi.org/10.1111/j.1469185X.1963.tb00791.x

Diamond JM (1975) Assembly of species communities. In: Cody ML, Diamond JM (Eds) Ecology and evolution of communities. Belknap Press, Cambridge, MA, 342-444.

Dick-Peddie WA (1993) New Mexico vegetation: Past, present and future. University of New Mexico Press, Albuquerque, NM.

Dregne HE (1986) Desertification of arid lands. In: El-Baz F, Hassan MHA (Eds) Physics of desertification. Martinus Nijhoff Publishers. Boston, MA, 4-34. https://doi.org/10.1007/978-94-009-4388-9_2

Edwards RL (1960) Relationship between grasshopper abundance and weather conditions in Saskatchewan, 1930-1958. Canadian Entomologist 92: 619-623. https://doi.org/10.4039/Ent92619-8

Fielding DJ, Brusven MA (1990) Historical analysis of grasshopper (Orthoptera: Acrididae) population responses to climate in southern Idaho, 1950-1980. Environmental Entomology 19: 1786-17-91.
Fielding DJ, Brusven MA (1993) Grasshopper (Orthoptera: Acrididae) community composition and ecological disturbance on southern Idaho rangeland. Environmental Entomology 22: 71-81. https://doi. org/10.1093/ee/22.1.71

Fielding DJ, Brusven MA (1995a) Ecological correlations between rangeland grasshopper (Orthoptera: Acrididae) and plant communities of southern Idaho. Environmental Entomology 24: 1432-1441. https:// doi.org/10.1093/ee/24.6.1432

Fielding DJ, Brusven MA (1995b) Grasshopper densities on grazed and ungrazed rangeland under drought conditions in southern Idaho. Great Basin Naturalist 55: 352-358.

Fielding DJ, Brusven MA (1996) Livestock grazing and grasshoppers: an interregional perspective. University of Idaho, College of Agriculture. Bulletin No. 785. 12 pp.

Fleischner TL (1994) Ecological costs of livestock grazing in western North America. Conservation Biology 8: 629-644. https://doi.org/10.1046/ j.1523-1739.1994.08030629.x

Gage SH, Mukerji MK (1977) A perspective of grasshopper populations distribution in Saskatchewan and interrelationship with weather. Environmental Entomology 6: 469-479. https://doi.org/10.1093/ ee/6.3.469

Gebeyehu S, Samways MJ (2003) Responses of grasshopper assemblages to long-term grazing management in semi-arid African savanna. Agriculture, Ecosystems and Environment 95: 613-622. https://doi. org/10.1016/S0167-8809(02)00178-0

Griffith GE, Omernik JM, McGraw MM, Jacobi GZ, Canavan CM, Schrader TS, Mercer D, Hill R, Moran BC (2006) Ecoregions of New Mexico (color poster with map, descriptive text, summary tables, and photographs): Reston, Virginia, U.S. Geological Survey (map scale $1: 1,400,000)$.

Gutzler DS (2013) Special feature: sustainability on the U.S./Mexico border, regional climatic considerations for borderlands sustainability. Ecosphere 47: 1-12.

Gutzler DS, Robbins TO (2011) Climate variability and projected change in the western United States: Regional downscaling and drought statistics. Climate Dynamics 37: 835-849. https://doi.org/10.1007/ s00382-010-0838-7

Hong-Shi L (1991) Guild structure of grasshopper community in the grassland of west Jilin Province. Acta Ecologica Sinca 11: 73-79.

Jepsen-Innes K, Bock CE (1989) Response of grasshoppers (Orthoptera: Acrididae) to livestock grazing in southeastern Arizona: Differences between season and subfamilies. Oecologia 78: 430-431. https://doi. org/10.1007/BF00379121

Joern A (1979) Resource utilization and community structure in assemblages of arid-grasshoppers. Transactions of the American Entomological Society 105: 253-300.

Joern A (1982) Vegetation structure and microhabitat selection in grasshoppers (Orthoptera: Acrididae). Southwestern Naturalist 27: $197-$ 209. https://doi.org/10.2307/3671144

Joern A (1985) Grasshopper dietary (Orthoptera: Acrididae) from a Nebraska sand hills prairie. Transactions of the Nebraska Academy of Sciences 13: 21-32.

Joern A, Gaines SB (1990) Population dynamics and regulation in grasshoppers. In: Chapman RF, Joern A (Eds) Biology of grasshoppers. John Wiley and Sons, New York, NY, 415-482.

Joern A, Lawlor LR (1981) Guild structure in grasshopper assemblages based on food and microhabitat resources. Oikos 37: 93-104. https:// doi.org/10.2307/3544078

Jonas JL, Joern A (2007) Grasshopper (Orthoptera: Acrididae) communities respond to fire, bison grazing and weather in North American tallgrass prairie: a long-term study. Oecologia 153: 699-711. https:// doi.org/10.1007/s00442-007-0761-8

Jones A (2006) Effects of cattle grazing on North American arid ecosystems: A quantitative review. Western North American Naturalist 60: 155-164.

Kang L, Li CH, Chen YL (1989) Studies on the relationships between distribution of orthopterans and vegetation types in the Xilin River Basin district of Inner Mongolia Autonomous Region. Chinese Journal of Plant Ecology 13: 341-349. 
Kang L, Chen YL (2008) Dynamics of grasshopper communities under different grazing intensities in Inner Mongolian steppes. Insect Science 2: 265-281. https://doi.org/10.1111/j.1744-7917.1995.tb00048.x

Key KHL (1959) The ecology and biogeography of Australian grasshoppers and locusts. In: Keast A, Cocker RL, Christian CS (Eds) Biogeography and Ecology in Australia. Dr. W. Junk, The Haag, Denmark, 192-210. https://doi.org/10.1007/978-94-017-6295-3_11

Laycock WA (1994) Implications of grazing vs. no grazing on today's rangelands. In: Vavra M, Laycock WA, Pieper RD (Eds) Ecological implications of livestock herbivory in the West. Society for Range Management, Denver, CO, 250-280.

Lightfoot DC (1985) Substrate utilization and guild structure in desert grasshopper assemblages. Master of Science Thesis. Department of Biology, New Mexico State University, Las Cruces, NM, USA. New Mexico State University Library, Thesis Archive. http://libcat.nmsu. edu/vwebv/holdingsInfo?bibId $=286088$

Lockwood JA (2011) The ontology of biological groups: Do grasshoppers form assemblages, communities, guilds, populations or something else? Psyche, Article ID:501983: 1-9. https://doi. org/10.1155/2011/501983

McCune B, Grace JB (2002) Analysis of ecological communities. MjM Software Design, Gleneden Beach, Oregon.

Mulkern GB (1967) Food selection by grasshoppers. Annual Review of Entomology 12: 59-78. https://doi.org/10.1146/annurev. en.12.010167.000423

Mulkern GB (1982) Multideminsionial analysis of overlap in resource utilization by grasshoppers. Transactions of the American Entomological Society 108: 1-9.

Nelson R (1988) Dryland management: The desertification problem. Environmental Department Working Paper No. 8, World Bank, Washington, DC.

NOAA (2016) Oceanic Nino Index. National Oceanographic and Atmospheric Administration. https://www.esrl.noaa.gov/psd/enso/past_ events.html [Accessed, June 14, 2017]

Nufio CR, McGuire CR, Bowers MD, Guralnick RP (2010) Grasshopper community response to climatic change: Variation along an elevational gradient. PLoS ONE:5e12977: 1-11. https://doi.org/10.1371/ journal.pone.0012977

Onsager JA (1977) Comparison of five methods for estimating density of rangeland grasshoppers. Journal of Economic Entomology 70: 187-190.

Otte D (1976) Species richness patterns of New World desert grasshoppers in relation to plant diversity. Journal of Biogeography 3: 197-209. https://doi.org/10.2307/3038010

Otte D, Joern A (1977) On feeding patterns in desert grasshoppers and the evolution of specialized diets. Proceedings of the Academy of Natural Sciences of Philadelphia 128: 89-126.

Padft RE (1982) Density and diversity of grasshoppers in an outbreak on Arizona rangeland. Environmental Entomology 11: 690-694. https:// doi.org/10.1093/ee/11.3.690

Parmesan C (2006) Ecological and evolutionary responses to recent climate change. Annual Review of Ecology, Evolution and Systematics 37: 637-669. https://doi.org/10.1146/annurev.ecolsys.37.091305.110100

Peters DPC, Havstad KM, Archer SR, Sala OE (2015) Beyond desertification: New paradigms for dryland landscapes. Frontiers in Ecology and the Environment 13: 4-12. https://doi.org/10.1890/140276

Pieper RD (1994) Ecological implications of livestock grazing. Pp 1-12. In: Vavra M, Laycock WA, Pieper RD (Eds) Ecological implications of livestock herbivory in the West. Society for Range Management, Denver, CO.

Prendini L, Theron L-J, Van der Merwe K, Owen-Smith N (1996) Abundance and guild structure of grasshoppers (Orthoptera: Acridoidea) in communally grazed and protected savanna. South African Journal of Zoology 31: 120-130. https://doi.org/10.1080/02541858.1996.11448403

Quinn MA, Walgenbach DD (1990) Influence of grazing history on the community structure of grasshoppers of a mixed-grass prairie. Environmental Entomology 19: 1756-1766. https://doi.org/10.1093/ ee/19.6.1756
Rambo JL, Faeth SH (1999) Effect of vertebrate grazing on plant and insect community structure. Conservation Biology 13: 1047-1054. https:// doi.org/10.1046/j.1523-1739.1999.98504.x

Richman DB, Lightfoot DC, Sutherland CA, Ferguson DJ (1993) A manual of the grasshoppers of New Mexico. New Mexico State University, Cooperative Extension Service, Handbook No. 7.

Rodell CF (1977) A grasshopper model for a grassland ecosystem. Ecology 58: 227-245. https://doi.org/10.2307/1935600

Root RB (1967) The niche exploitation pattern of the blue-gray gnatcatcher. Ecological Monographs 37: 317-350. https://doi. org/10.2307/1942327

Rosenzweig C, Karoly D, Vicarelli M, Neofotis P, Wu QG, Casassa G, Menzel A, Root TL, Estrella N, Seguin B, Tryjanowski P, Liu C, Rawlins S, Imeson A (2008) Attributing physical and biological impacts to anthropogenic climate change. Nature 453: 353-357. https://doi. org/10.1038/nature06937

Savitsky VY (2010) Trophic relationships and their importance for biotopic distribution of grasshoppers (Orthoptera, Acridoidea) in semi-deserts of the lower Volga River area. Entomologicheskoe Obozrenie 89: 333-366. https://doi.org/10.1134/S0013873810070031

Seager R, Ting M, Held I, Kushnir Y, Lu J, Vecchi G, Huang H-P, Harnik N, Leetmaa A, Lau N-C, Li C, Velez J, Naik N (2008) Model projections of an imminent transition to a more arid climate in southwestern North America. Science 316: 1181-1184. https://doi.org/10.1126/science. 1139601

Street DA, McGuire MR (1990) Pathogenic diseases of grasshoppers. In: Chapman RF, Joern A (Eds) Biology of grasshoppers. John Wiley and Sons, New York, NY, 483-516.

Sun W, Lei Z, Zang Z, Dong H, Qian H, Cong B (2013) Guild structure of grasshopper communities in hilly meadow steppe of Horqin plain, North China. Chinese Journal of Ecology 32: 1269-1276.

Torrusio S, Cigliano MM, Wysiecki ML (2002) Grasshopper (Orthoptera: Acridoidea) and plant community relationships in the Argentine pampas. Journal of Biogeography 29: 221-229. https://doi. org/10.1046/j.1365-2699.2002.00663.x

USDA PLANTS Database (2017) https://plants.usda.gov/java/ [Accessed June 3, 2017]

Uvarov BP (1977) Grasshoppers and locusts: A handbook of general acridology. Vol. 2. Life-forms, ecofaunas and life-zones. Centre for Overseas Pest Research, London, 371-444.

Van der Plas F, Anderson TM, Olff H (2012) Trait similarity patterns within grass and grasshopper communities: multitrophic community assembly at work. Ecology 93: 836-846. https://doi.org/10.1890/110975.1

York JC, Dick-Peddie WA (1969) Vegetation changes in southern New Mexico during the past hundred years. In: McGinnes WG, Goldman BJ (Eds) Arid lands in perspective. University of Arizona Press, Tucson, $A Z, 157-166$.

Young JA (1994) Historical and evolutionary perspectives on grazing of Western rangelands. In: Vavra M, Laycock WA, Pieper RD (Eds) Ecological implications of livestock herbivory in the West. Society for Range Management, Denver, CO, 1-12.

\section{Supplementary material 1}

Author: David C. Lightfoot

Data type: MS Word file

Explanation note: Supplementary figures.

Copyright notice: This dataset is made available under the Open Database License (http://opendatacommons.org/licenses/ odbl/1.0/). The Open Database License (ODbL) is a license agreement intended to allow users to freely share, modify, and use this Dataset while maintaining this same freedom for others, provided that the original source and author(s) are credited.

Link: https://doi.org/10.3897/jor.27.19945.suppl1 


\section{Supplementary material 2}

Author: David C. Lightfoot

Data type: MS Word file

Explanation note: Supplementary tables 1, 2 and 5.

Copyright notice: This dataset is made available under the Open Database License (http://opendatacommons.org/licenses/ odbl/1.0/). The Open Database License (ODbL) is a license agreement intended to allow users to freely share, modify, and use this Dataset while maintaining this same freedom for others, provided that the original source and author(s) are credited.

Link: https://doi.org/10.3897/jor.27.19945.suppl2

\section{Supplementary material 3}

Author: David C. Lightfoot

Data type: Microsoft Excel Worksheet (.xlsx)

Explanation note: Supplementary table 3.

Copyright notice: This dataset is made available under the Open Database License (http://opendatacommons.org/licenses/ odbl/1.0/). The Open Database License (ODbL) is a license agreement intended to allow users to freely share, modify, and use this Dataset while maintaining this same freedom for others, provided that the original source and author(s) are credited.

Link: https://doi.org/10.3897/jor.27.19945.suppl3

\section{Supplementary material 4}

Author: David C. Lightfoot

Data type: Microsoft Excel Worksheet (.xlsx)

Explanation note: Supplementary table 4.

Copyright notice: This dataset is made available under the Open Database License (http://opendatacommons.org/licenses/ odbl/1.0/). The Open Database License (ODbL) is a license agreement intended to allow users to freely share, modify, and use this Dataset while maintaining this same freedom for others, provided that the original source and author(s) are credited.

Link: https://doi.org/10.3897/jor.27.19945.suppl4 